\title{
AD HOC OR INSTITUTIONAL ARBITRATION-A CLEAR-CUT DISTINCTION? A CLOSER LOOK AT BORDERLINE CASES
}

\author{
Ulrich G. Schroeter
}

\begin{abstract}
It is generally accepted in both theory and practice of arbitration that there are two basic forms of arbitration, ad hoc and institutional. This long established dichotomy has rarely been questioned, and it has mostly worked well in international arbitration practice.

The present contribution investigates the traditional distinction between ad hoc and institutional arbitration in more detail by looking at "borderline cases", i.e. constellations that cannot easily be allocated to one of these two categories. Four groups of borderline cases are discussed: (1) UNCITRAL arbitrations, in particular those administered by arbitral institutions; (2) cases in which the parties have chosen institutional rules, but not the issuing institution (and vice versa), (3) the modification of institutional rules by the parties and the identification of a possible "mandatory" core of institutional rules, and (4) "mix and match" (or "hybrid") arbitrations combining one arbitral institution's rules with the case's administration by a different arbitral institution.

$B y$ identifying the factors that were decisive for these borderline cases being regarded as institutional or ad hoc, the article is trying to gain insight into the core characteristics underlying each arbitration category. Drawing on these insights, it develops and explains a novel definition of "institutional arbitration".
\end{abstract}

\footnotetext{
* Professor of Law, Faculty of Law, University of Basel (Switzerland). The author can be reached at: mail@ulrichschroeter.com.
} 
KEYWORDS: ad hoc arbitration, institutional arbitration, international arbitration, arbitral institutions, 1958 New York Convention, 1961 Geneva Arbitration, UNCITRAL Model Law, UNCITRAL Arbitration Rules, mandatory institutional rules, hybrid arbitrations, mix and match arbitrations, administration of arbitrations 


\section{INTRODUCTION}

In both theory and practice of arbitration, it is generally agreed that there are two basic forms of arbitration, ad hoc and institutional. ${ }^{1}$ This truism is so self-understood that it has rarely been challenged, and few attempts have been made to identify what precisely makes an arbitration institutional or ad hoc. The latter is somewhat surprising, given that the principle of party autonomy prevailing in arbitration can result in a great variety of dispute settlement designs that may not always be easily accommodated by these two categories that have interchangeably been referred to as "forms", "kind", " "types" or "categories" of arbitration. (Article IV(6) of the 1961 European Convention on International Commercial Arbitration, ${ }^{3}$ one of the few provisions in international arbitration law that expressly addresses the distinction between ad hoc and institutional arbitration, speaks of "mode of arbitration".)

The present article seeks to investigate the traditional distinction between the two forms of arbitration by looking at "borderline cases", i.e., constellations that are not easily allocated to either category. By identifying the factors eventually decisive for making the respective arbitrations institutional or ad hoc, it is hoped that insight can be gained into the core characteristics of each arbitration type. The article will proceed as follows: In Part II, it will outline accepted definitions of the two traditional arbitration categories, before clarifying in Part III whether and why the distinction matters at all. Part IV turns to four types of borderline cases and the lessons to be learned from them for the delimitation of arbitration categories. Part V summarizes the results and draws consequences by outlining a novel definition of institutional arbitration, before Part VI briefly concludes.

\footnotetext{
${ }^{1}$ Bovis Lend Lease Pte. Ltd. v. Jay-Tech Marine \& Projects Pte. Ltd., [2005] SGHC 91, ๆ 21 (Sing.) [hereinafter Bovis]; Gerald Aksen, Ad Hoc Versus Institutional Arbitration, 2(1) ICC BULL. 8, 8 (1991); GARy B. Born, International Commercial Arbitration 169 (2d ed. 2014); P. A. Lalive, Problèmes Relatifs à l'Arbitrage International Commercial, 120 ACADÉMIE DE DROIT INTERNATIONAL, RECUEIL DES COURS 568, 664 (1967); JULIAN D. M. LEW ET AL., COMPARATIVE INTERNATIONAL COMMERCIAL ARBITRATION I 3-4 (2003); MiCHAEL MCILWRATH \& JOHN Savage, international Arbitration and Mediation: A Practical Guide 1 1-063 (2010); Jan Heiner Nedden \& Axel Benjamin Herzberg, Einleitung, in ICC-SCHO/DIS-SCHO: PRAXISKOMMENTAR ZU DEN SCHIEDSGERICHTSORDNUNGEN 1, 9 (Jan Heiner Nedden \& Axel Benjamin Herzberg eds., 2014); Anne Véronique Schlaepfer \& Angelina M. Petti, Institutional Versus Ad Hoc Arbitration, in INTERNATIONAL ARBITRATION IN SWITZERLAND: A HANDBOOK FOR PRACTITIONERS 13 (Elliott Geisinger \& Nathalie Voser eds., 2d ed. 2013).

${ }^{2}$ Insigma Technology Co. Ltd. v. Alstom Technology Ltd., [2009] SGCA 24, 3 Singapore Law Reports (Reissue) 936, 934 (Sing.) [hereinafter Insigma v. Alstom].

${ }^{3}$ European Convention on International Commercial Arbitration, opened for signature Apr. 21, 1961, 484 U.N.T.S. 364 [hereinafter 1961 Geneva Convention].
} 


\section{ACCEPTED Definitions OF ARbitration CATEgories}

\section{A. The Traditional Ad Hoc/Institutional Arbitration Dichotomy}

The importance of party autonomy is well established in international arbitration. ${ }^{4}$ Its exercise can take various forms. One of these forms, namely party autonomy to submit to arbitration, is primarily exercised by the parties jointly deciding whether to go to ad hoc arbitration or to choose institutional arbitration. ${ }^{5}$ It is therefore not surprising that these two traditional modes of arbitration are most often discussed with a view to the parties' choice between them, ${ }^{6}$ and the categories of ad hoc arbitration on one hand and institutional arbitration on the other are generally presented in terms of their perceived advantages and disadvantages. ${ }^{7}$ This approach accordingly regards the dichotomy of arbitration categories as a menu that parties can choose from: There are set meals (institutional arbitration), and there is dining à la carte (ad hoc arbitration).

When it comes to defining the two categories on the menu, it is interesting that no truly universally used definition for either ad hoc arbitration or institutional arbitration can be identified. ${ }^{8}$ In spite of this, the definitions used in major arbitration textbooks are at least quite similar. In addition, many arbitration treatises also agree by first defining institutional arbitration and addressing ad hoc arbitration second, thereby indicating ad hoc arbitration's default character.

\footnotetext{
${ }^{4}$ Thomas E. Carbonneau, The Law and Practice of Arbitration 21-22 (2d ed. 2007); FOUCHARD GAILLARD GOLDMAN ON INTERNATIONAL COMMERCIAL ARBITRATION q 46 (Emmanuel Gaillard \& John Savage eds., 1999) [hereinafter FOUCHARD GAILLARD GOLDMAN]; Nigel Blackaby ET AL., REDFERN AND HunTER ON INTERNATIONAL ARBITRATION 6.07 (6th ed. 2015)

${ }^{5}$ Karl-Heinz Böckstiegel, Party Autonomy and Case Management-Experiences and Suggestions of an Arbitrator, 11 SCHIEDSVZ 1, 2 (2013); BORN, supra note 1, at 168-69; Kinga Timár, The Legal Relationship Between the Parties and the Arbitral Institution, 2013(1) ELTE L.J. 103, 105 (2013).

${ }^{6}$ CARBonneaU, supra note 4, at 10, 626; BlackABy ET AL., supra note 4, $\uparrow \uparrow 1$ 1.140, 2.79; Timár, supra note 5, at 105-07; ANDREW TwEEDDAlE \& KEREN TwEEDDAlE, ARBitration OF COMMERCIAL DISPUTES $₫ 3.01$ (2005).

${ }^{7}$ See BoRN, supra note 1, at 171; Dana H. Freyer, Practical Considerations in Drafting Dispute Resolution Provisions in International Commercial Contracts: A US Perspective, 15(4) J. INT'L ARB. 7, 20-23 (1998); BLACKABY ET AL., supra note 4, ๆๆ 1.140-56; Schlaepfer \& Petti, supra note 1, at 14-17, 20-21; William K. Slate II, International Arbitration: Do Institutions Make A Difference?, 31 WAKE FOREST L. REV. 41, 52-59 (1996).

${ }^{8}$ Pilar Perales Viscasillas, The Role of Arbitral Institutions Under the 2010 UNCITRAL Arbitration Rules, 6 LIMA ARB. 26, 31 (2014).
} 


\section{B. Defining Institutional Arbitration}

In doing so, an "institutional" arbitration has been described as one that is administered by a specialist arbitral institution under its own rules of arbitration. ${ }^{9}$ According to another definition, institutional arbitrations are conducted pursuant to institutional arbitration rules, almost always overseen by an administrative authority with responsibility for various aspects relating to constituting the arbitral tribunal, fixing the arbitrators' compensation and similar matters. ${ }^{10} \mathrm{~A}$ yet different definition regards institutional arbitration as an arbitration procedure conducted under the auspices of or administered or directed by an existing institution. ${ }^{11}$

The above range of definitions indicates that no single comprehensive definition of institutional arbitration has yet been developed. Nevertheless, the already mentioned attempts at a definition as well as a few others ${ }^{13}$ show significant similarities by mostly employing the same two components: The institution's administration of arbitration proceedings, and its publication of institutional arbitration rules. Differences primarily result from the emphasis, if any, that is put on one or the other component. While some consider the administration by the institution as the more important factor, ${ }^{14}$ others focus primarily on the institutional rules, ${ }^{15}$ and yet others regard both components as equally important. ${ }^{16}$

\footnotetext{
${ }^{9}$ BLACKABY ET AL., supra note 4, ๆ 1.140; Bovis, supra note 1, ๆ 21; Slate, supra note 7, at 47;

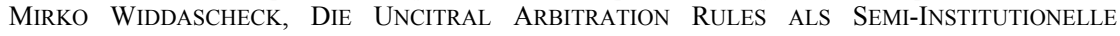
SCHIEDSVERFAHRENSREGELN 14 (2016); see also CHRISTIAN BÜHRING-Uhle ET AL., ARBITRATION AND MEDIATION IN INTERNATIONAL BusinESS 33 (2d ed. 2006); Rolf A. Schütze, Introduction, in InSTITUTIONAL ARBITRATION 1, $\mid 1$ (Rolf A. Schütze ed., 2013).

${ }^{10}$ BORN, supra note 1 , at 169.

${ }^{11}$ LEW ET AL., supra note 1, ๆ 3-6; see also Perales Viscasillas, supra note 8, at 32.

12 Barbara Alicja WARWAS, The Liability OF ARBITRAL InSTITUTIONS: Legitimacy ChALLENGES AND FUnCTIONAL RESPONSES 20 (2017); see also Lalive, supra note 1, at 664.

${ }^{13}$ See also KARL HeInz SCHWAB \& Gerhard WALTER, SCHIEDSGERICHTSBARKeit 10 (7th ed. 2005); TWEEDDALE \& TWEEDDALE, supra note 6 , ๆ 3.01 .

${ }^{14}$ Helena Hsi Chia Chen, A Review of the Taiwanese Court's Ruling on Ad Hoc Arbitral Awards, 20 ASIA PAC. L. REV. 89, 92 (2012); JACOB GRIERSON \& ANNET VAN HoOfT, ARBITRATING UNDER THE 2012 ICC RULES 28 (2012); LEW ET AL., supra note 1, \ 3-6; Perales Viscasillas, supra note 8, at 32; Friederike Schäfer, Institutionelle Schiedsgerichtsbarkeit - Allgemeines, in HANDBUCH SCHIEDSGERICHTSBARKEIT 308 (Hellwig Torggler et al. eds., 2017); Schlaepfer \& Petti, supra note 1, at 19; PETER SCHLOSSER, DAS ReCHT DER INTERNATIONALEN Privaten SCHIEDSGERICHTSBARKEIT 9599 (2d ed. 1989); WeI Sun \& MELANIE Willems, ARBitration in

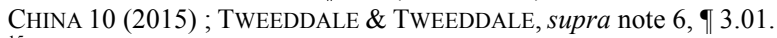

${ }^{15}$ BORN, supra note 1, at 169; BÜHRING-UHLE ET AL., supra note 9, at 33; SCHWAB \& WALTER, supra note 13, 10; HERMAN VERBIST ET AL., ICC ARBITRATION IN PRACTICE 10 (2d ed. 2015) .

${ }^{16}$ BLACKABY ET AL., supra note 4, ๆ 1.140; Schütze, supra note 9, ๆ 1; Slate, supra note 7, at 47; P.J. VAN OMMEREN, RAPPORT AU CONGRÈS INTERNATIONAL DE L'ARBITRAGE 2 (1961).
} 


\section{Defining Ad Hoc Arbitration}

In contrast, ad hoc arbitration has primarily been defined as the opposite of institutional arbitration, as a category encompassing all arbitrations that are not institutional. "Negative" definitions of this kinds describe ad hoc arbitration as arbitrations that are conducted without the involvement of any arbitral institution, ${ }^{18}$ that are independent of all institutions, ${ }^{19}$ that are conducted without the benefit of an appointing and administrative authority or (generally) preexisting arbitration rules ${ }^{20}$ or that are not administered by an arbitral institution. ${ }^{21}$ Almost mirroring the various attempts at defining institutional arbitration, ${ }^{22}$ they thereby range from no institutional involvement at all via neither institutional administration nor use of institutional rules to (merely) no institutional administration. The prevailing "negative" approach of these definitions reflects the default nature of ad hoc arbitration, given that an arbitration will be ad hoc whenever parties are silent about their desired arbitration mode. $^{23}$

Positive descriptions of this arbitration type are only rarely encountered. An example can be found in Article I(2)(b) of the 1961 Geneva Convention, where ad hoc arbitration is defined as "settlement by arbitrators appointed for each case".

\section{Challenges to the Traditional Dichotomy}

In recent years, the traditional ad hoc/institutional dichotomy has occasionally been challenged in legal writings. Authors have inter alia pointed out that the borderline between the two categories is not always clear, ${ }^{24}$ and that difficulties are encountered in certain cases to distinguish between them. ${ }^{25}$ Much in the same way, it has been regarded as generally inappropriate to only consider the differences between ad hoc and

\footnotetext{
${ }^{17}$ Pieter Sanders, Commentary on UNCITRAL Arbitration Rules, 2 YeARBOOK COM. ARB. 172, ๆ 2.4 (1977).

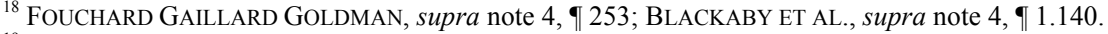

${ }^{19}$ LEW ET AL., supra note 1, ๆ 3-9; Schlaepfer \& Petti, supra note 1, at 13-14.

${ }^{20}$ BORN, supra note 1 , at 169.

${ }^{21}$ DAVID St. John SutTon et AL., RusSEll on ARBitration 9 2-006 (23th ed. 2007); Jennifer Kirby, Insigma Technology Co. Ltd. v. Alstom Technology Ltd.: SIAC Can Administer Cases Under the ICC Rules?!?, 25(3) ARB. INT'L 319, 324 (2009); BÜHRING-UHLE ET AL., supra note 9, at 35; SUN \& WILLEMS, supra note 14 , at 10.

${ }^{22}$ Supra Section II.B.

${ }^{23}$ LEW ET AL., supra note 1, $\mid$ 3-5; Perales Viscasillas, supra note 8, at 35.

${ }^{24}$ Jean-Babtiste Racine, Note, 22 Janvier 2010, Tribunal de Grande Instance de Paris, 2010(3) REVUE DE L'ARBITRAGE 571, 581-82 (2010); TWEEDDALE \& TWEEDDALE, supra note 6, ๆ 3.02; CHRISTIAN WOLF, DIE INSTITUTIONELLE HANDELSSCHIEDSGERICHTSBARKEIT 10 (1992).

${ }^{25}$ Perales Viscasillas, supra note 8, at 51.
} 
institutional arbitration in the extreme without considering hybrid models. ${ }^{26}$ Others have stressed that the distinction in any case should not be overestimated. $^{27}$

The present contribution takes up these challenges and tests their justification by looking at a number of "borderline cases", i.e., cases in which the seemingly clear-cut line between institutional and ad hoc arbitration has proven difficult to draw. In investigating such borderline constellations and their treatment both in case law and in academic discussions, an attempt will be made to determine what lessons, if any, can be learned from them for the general distinction between arbitration categories.

\section{WHY DOES THE DISTINCTION MATTER?}

Before we turn to these borderline cases, it seems appropriate to ask why the distinction between ad hoc and institutional arbitration, clear-cut or not, actually matters. Commentators have stressed in a generic manner that institutional arbitrations are different, both in fact and law, from ad hoc arbitrations, ${ }^{28}$ and that these differences are vitally important. ${ }^{29}$ In looking for the source of these differences, three possible reasons come to mind.

\section{A. Differences in Applicable Procedural Rules}

First of all, the distinction between $a d$ hoc and institutional arbitration seemingly matters because of the different rules of procedure that apply in these arbitrations. Indeed, the difference between the parties "own" rules of procedure established in an ad hoc arbitration and the time-tested, but generic procedural rules laid down by established arbitral institutions, sometimes likened to the difference between a tailor-made suit and one that is bought "off the peg", ${ }^{30}$ has often been stressed.

However, upon closer scrutiny it becomes clear that the differences in the applicable procedural rules do not (or at least not primarily) depend on the arbitration type that a specific arbitration belongs to, but on the specific rules that apply to a particular arbitration due to either the parties' agreement, or according to the default regime of the lex arbitri. In other words, the decisive factor is not the distinction between ad hoc arbitration on one hand and institutional arbitration on the other, but rather the specific

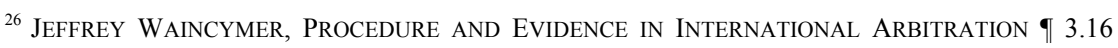
(2012).

${ }^{27}$ Racine, supra note 24 , at 581-82.

${ }^{28}$ FOUCHARD GAILLARD GOLDMAN, supra note $4, \boldsymbol{\uparrow} 812$.

${ }^{29}$ BORN, supra note 1 , at 169.

${ }^{30}$ BLACKABY ET AL., supra note 4, $\uparrow 1.143$; TwEEDDALE \& TwEEDDALE, supra note $6, \boldsymbol{\Upsilon} 3.77$.
} 
set of rules governing the specific arbitration proceedings. In this respect, it should be kept in mind that significant differences also exist between different institutional rules and the role they allocate to the administering institution, ${ }^{31}$ sometimes referred to as "hands-off approach" (as e.g., London Court of International Arbitration (LCIA) arbitrations) vs. "handson approach" (as notably ICC International Court of Arbitration (ICC) arbitrations). ${ }^{32}$ Notwithstanding the differences in procedural rules, these arbitrations are nevertheless indiscriminately recognized as "institutional". ${ }^{33}$ In fact, an arbitration involving an arbitral institution that fulfils only very limited tasks may well appear closer to an ad hoc proceeding than to a fully-administered institutional arbitration. It is therefore submitted that the differences in applicable procedural rules are not what gives relevance to the precise delimitation between arbitration categories.

\section{B. Practical Differences}

A second group of reasons why the ad hoc/institutional distinction matters may be referred to as "practical differences", in the sense that these differences do not directly lie in the rules of procedure applicable to the two types of arbitrations. Some of these practical differences are direct consequences of the procedure in ad hoc vs. institutional arbitration, ${ }^{34}$ as e.g., the strategic options available to a claimant when confronted with a respondent who refuses to nominate an arbitrator. Insofar, differences of this type are mere extensions of the differences in the respective rules of procedure addressed earlier. $^{35}$

Other practical differences are less directly determined by procedural rules. An example is the extra cachet that institutional awards supposedly carry in comparison to awards rendered ad hoc. ${ }^{36}$ In an oft-quoted assessment, this not strictly judicial, but rather 'soft' factor has been described as there being "something more majestic, more dignified and more comforting" about institutional arbitral awards. ${ }^{37}$ However, it is submitted that this perception and the practical consequences emanating therefrom (as e.g., an easier enforceability of institutional awards) depend

\footnotetext{
${ }^{31}$ Timár, supra note 5 , at 107.

32 See RÉmy Gerbay, The Functions of ARbitral InSTITUtions 45 (2016); Practitioner's HANDBOOK ON INTERNATIONAL COMMERCIAL ARBITRATION $\uparrow 18.20$ (Frank-Bernd Weigand ed., 2009); see also LEW ET AL., supra note 1, ๆ 3-19.

${ }^{33}$ Infra Section IV.A.3.(c).

${ }^{34}$ See MCILWRATH \& SAVAGE, supra note 1, 1 1-146.

${ }^{35}$ Supra Section III.A.

${ }^{36}$ LEW ET AL., supra note 1, ๆ 3-20; BORN, supra note 1, at 171; BÜHRING-UHLE ET AL., supra note 9, at 36; Schlaepfer \& Petti, supra note 1, at 20.

${ }^{37}$ Francis J. Higgins et al., Pitfalls in International Commercial Arbitration, 35 Bus. L. 1035, 1051 (1980).
} 
less on the arbitration being "institutional", but rather on the particular institution's reputation in the field. Instead of the cachet of institutional arbitration as a category, it is therefore the cachet of a particular arbitral institution that makes the practical difference. ${ }^{38}$ The same is true for another practical advantage of institutional arbitration that is sometimes mentioned, namely the "comfort" element in an arbitral institution's existence: ${ }^{39}$ As parties will draw such comfort from a particular institution's experience and reputation, that institution's involvement in an arbitration makes the difference, and not the proceedings' categorization as "institutional".

\section{Legal Differences That Depend on the Precise Definition of Arbitration Categories}

Accordingly, it is but a third reason that can make the precise distinction between ad hoc and institutional arbitration relevant: The exact delimitation of these traditional kinds of arbitration matters where legal rules of arbitration law, either of international or domestic provenance, attach legal consequences to this distinction by distinguishing between the two categories. Such rules of law are not common, but they do exist. In addressing them, it is helpful to differentiate according to the consequences that a rule attaches to the ad hoc/institutional distinction. The result is a group of legal provisions we can refer to as "category inclusive" rules of arbitration law, to be addressed first, before we turn to a second group of "category exclusive" rules of arbitration law.

1. "Category Inclusive" Rules of Arbitration Law — The first group of arbitration law provisions refers to $a d$ hoc and/or institutional arbitrations, but treats both types of arbitration alike. Category inclusive rules therefore connect no legal consequences to the ad hoc/institutional distinction. An example from international arbitration law is Article I(2) of the 1958 New York Convention, ${ }^{40}$ which provides that "[t]he term 'arbitral awards' shall include not only awards made by arbitrators appointed for each case but also those made by permanent arbitral bodies to which the parties have submitted." Although the reference to "permanent arbitral bodies" was historically inserted in order to accommodate permanent bodies like Arbitration Commissions for External Trade that were a feature of jurisprudence in the then-Socialist States, ${ }^{41}$ case law under Article I(2) of

\footnotetext{
${ }^{38}$ See LEW ET AL., supra note 1, 9 3-20; BÜHRING-UHLE ET AL., supra note 9, at 36.

${ }^{39}$ Lalive, supra note 1, at 668; LEW ET AL., supra note 1, ๆ 3-20.

${ }^{40}$ Convention on the Recognition and Enforcement of Foreign Arbitral Awards, opened for signature June 15, 1958, 330 U.N.T.S. 38 [hereinafter 1958 New York Convention].

${ }^{41}$ RECOGNITION AND ENFORCEMENT OF FOREIGN ARBITRAL AWARdS: A Global COMMENTARY ON THE NEW YORK CONVENTION 21 (Herbert Kronke et al. eds., 2010); MARIKE R. P. PAULSSON,
} 
the 1958 New York Convention has also applied the term to arbitral institutions ${ }^{42}$ like the Court of Arbitration at the Bulgarian Chamber of Commerce and Industry, ${ }^{43}$ the Arbitral Tribunal at the Vienna Commodity Exchange, ${ }^{44}$ the Arbitration Board of the Coffee Trade Federation in London, ${ }^{45}$ the Arbitral Tribunal according to the Conditions of Business of the Waren-Verein der Hamburger Börse e.V. ${ }^{46}$ or the ICC International Court of Arbitration. ${ }^{47}$ Similar provisions can be found in Article I(2)(b) of the 1961 Geneva Convention, stating that "the term 'arbitration' shall mean not only settlement by arbitrators appointed for each case (ad hoc arbitration) but also by permanent arbitral institutions", 48 and Article 2(a) of the 1985/2006 UNCITRAL Model Law on International Commercial Arbitration, ${ }^{49}$ which provides that "arbitration" means "any arbitration whether or not administered by a permanent arbitral institution". In domestic arbitration laws, comparable provisions are inter alia Article 182(1) of the Swiss Arbitration Law (IPRG), ${ }^{50} \S 1042(3)$ of the German Code of Civil Procedure, Article 832 of the Italian Code of Civil Procedure, Articles 1446, 1452-1454, 1456, 1464(3) and 1508 of the French Code of Civil Procedure, and section 24(2) of the 1996 English Arbitration Act.

Legal rules of this type primarily aim at confirming the existence and legitimacy of institutional arbitration. ${ }^{51}$ Today they may seem superfluous, as they merely confirm an internationally recognized principle. ${ }^{52}$ Due to their inclusive purpose, it does not matter under such provisions how the terms employed therein- "permanent arbitral bodies", "permanent arbitral

THE 1958 NEW YORK CONVENTION IN ACTION 121 (2016). More details on such arbitration commissions, also see Lalive, supra note 1, at 667-68.

${ }^{42}$ Equating "permanent arbitral bodies" under Article I(2) of the 1958 New York Convention with arbitral institutions, see SUN \& WILLEMS, supra note 14, at 12.

${ }^{43}$ Cassazione Sezione Civile [Cass.], Apr. 17, 1978, 4 YeArbook CoM. ARB. 282, 282-83 (1979) (It.).

${ }_{44}^{44}$ Corte di Appello di Ancona [App.], June 8, 1981, 8 YeArbooK COM. ARB. 389, 389 (1983) (It.).

${ }^{45}$ Tribunal Supremo [S.T.S.], Oct. 8, 1981, 8 YEARBOOK COM. ARB. 406, 406 (1983) (Spain).

${ }^{46}$ Bundesgerichtshof [BGH] [Federal Court of Justice] Dec. 2, 1982, III ZR 85/81, NEUE JURISTISCHE WOCHENSCHRIFT [NJW] 1267 (1268), 1983 (Ger.).

${ }^{47}$ FG Hemisphere Associates LLC v Democratic Republic of Congo [2010] NSWSC 1394, qๆ 8, 10 (Austl.).

${ }^{48}$ See Art. I(2)(b) of the 1961 Geneva Convention, supra Section II.C.

${ }^{49}$ United Nations Commission on International Trade Law Model Law (UNCITRAL) Model Law on International Commercial Arbitration (2006), http://www.uncitral.org/pdf/english/texts/arbitrati on/ml-arb/07-86998_Ebook.pdf [hereinafter UNCITRAL Model Law].

${ }^{50}$ Article 182(1) of the Swiss IPRG provides that the parties may regulate the arbitral procedure directly or by reference to rules of arbitration (schiedsgerichtliche Verfahrensordnung). The term "reference to rules of arbitration" is generally equated with a choice of institutional arbitration; see BERNHARD BERGER \& FRANZ KELLERHALS, INTERNATIONAL AND DOMESTIC ARBITRATION IN SWITZERLAND $\llbracket 22$ (3d ed. 2015).

${ }^{51}$ On Article I(2) of the 1958 New York Convention, see FouCHARD GAILlARD GOLDMAN, supra note 4, 253; see also BORN, supra note 1, at 2920.

${ }^{52}$ PAULSSON, supra note 41, at 120. 
institutions" or similar-are precisely defined, because awards emanating from such bodies are treated in the same way as other arbitral awards, notably those rendered in ad hoc arbitrations. ${ }^{53}$ Accordingly, "category inclusive" provisions make the distinction between ad hoc and institutional arbitration a moot point, leaving the precise delimitation of the two categories irrelevant.

2. "Category Exclusive" Rules of Arbitration Law — The position is different under "category exclusive" rules of arbitration law that refer to a particular arbitration category in order to treat it differently from another arbitration category. Provisions of this type are rare when compared to "category inclusive" legal provisions, but do occasionally occur.

(a) The 1961 Geneva Convention as an Example - Examples from international arbitration law can be found in Article IV of the 1961 Geneva Convention. Under the heading "Organization of the arbitration", Article IV(1) provides that the parties to an arbitration agreement are free to submit their disputes to either a permanent arbitral institution (Article IV(1)(a)) or an ad hoc arbitral procedure (Article IV(1)(b)), and stipulates different rules about the organization of these different "modes" of arbitration. ${ }^{54}$ Article IV(5) lays down a procedure for the determination of a permanent arbitral institution where the parties have agreed to submit their disputes to an arbitral institution, but have not determined which. ${ }^{55}$ Both Article IV(1)(a) and (b) as well as Article IV(5) of the 1961 Geneva Convention therefore only apply to institutional or ad hoc arbitrations and are accordingly "category exclusive". (In contrast, the neighbouring provisions in Articles IV(4)(d) and (6) of the same convention arguably belong to the 'category inclusive' type discussed earlier. ${ }^{56}$ )

(b) PRC Arbitration Law as an Example - Among domestic arbitration laws, the most prominent "category exclusive" rule is probably Article 16 in conjunction with Article 18 of the Arbitration Law of the Peoples' Republic of China. Article 16(2) of the Chinese Arbitration Law

\footnotetext{
${ }^{53}$ See MÜNChEnER Kommentar ZUR ZPO $\mid 7$ (Jens Adolphsen et al. eds., 2013).

${ }^{54}$ See Bundesgerichtshof [BGH] [Federal Court of Justice] Dec. 2, 1982, III ZR 85/81, NEUE JURISTISCHE WOCHENSCHRIFT [NJW] 1267 (1268), 1983 (Ger.).

${ }_{55}$ Bundesgerichtshof [BGH] [Federal Court of Justice] Dec. 2, 1982, III ZR 85/81, NEUE JURISTISCHE WOCHENSCHRIFT [NJW] 1267, 1983 (Ger.) concerned an imperfectly drafted arbitration clause with an unclear reference to "Hamburger freundschaftliche Arbitrage aufgrund der Waren-Verein der Hamburger Boerse e.V./Arbitraggio amichevole in conformita alle condizioni del Waren-Verein der Hamburger Boerse e.V.”: The German Federal Supreme Court held that both arbitral tribunals of the Hamburger freundschaftliche Arbitrage and arbitral tribunals under the Rules of the Waren-Verein der Hamburger Börse e.V. equally qualify as "permanent arbitral institutions" in accordance with Article IV(1) of the 1961 Geneva Convention, but declared the arbitration clause invalid because it remained unclear which of the two arbitral institutions it referred to. The decision has been criticized for not applying Article IV(5), (6) of the 1961 Geneva Convention; see SCHLOSSER, supra note 14, ๆ 559.

${ }^{56}$ Supra Section III.C.1.
} 
expressly lists "[t]he arbitration commission chosen" as one of the mandatory requirements of a valid arbitration agreement, and Article 18 of the Arbitration Law provides that the arbitration agreement will be considered invalid if the parties fail to designate an arbitration institution in the arbitration agreement. The requirement to choose an "arbitration commission"- - a term that equals the more commonly used "arbitration institution" 57 - is particular to the PRC's current arbitration law ${ }^{58}$ and effectively rules out any ad hoc arbitration in mainland China. ${ }^{59}$ While this means that the precise distinction between $a d$ hoc and institutional arbitration matters under the arbitration law of the PRC, the general delimitation of the two categories does not necessarily follow the same principles used elsewhere: This is so because Article 10 of the Arbitration Law provides a specific definition of the term "arbitration commission", 60 although its applicability in the context of Articles 16 and 18 is not entirely uncontroversial. ${ }^{61}$ According to commentators, the purpose of the Chinese lex arbitri's focus on institutional arbitration is to allow the government to conventiently monitor arbitral institutions and cases, ${ }^{62}$ a goal less easily reached in ad hoc arbitration.

(c) Taiwan Arbitration Law as an Example - A further example of "category exclusive" domestic arbitration rules is provided by the arbitration law of Taiwan. In the Jin Cheng Feng case, the Taiwanese courts adopted a (controversially) narrow interpretation of Article 37(1) of the 1998 Taiwan Arbitration Act and held that only an arbitration institution's award is binding on the parties and has the same validity as a final court judgment. ${ }^{63}$ A possible reason for this interpretation is that Taiwanese arbitration law does not include a counterpart to Article 2(a) of the UNCITRAL Model Law, ${ }^{64}$ a "category inclusive" provision mentioned

\footnotetext{
${ }^{57}$ John Mo, Probing the Uniformity of the Arbitration System in the PRC, 17(3) J. INT'L ARB. 1, 29 (2000); Jingzhou Tao \& Clarisse von Wunschheim, Articles 16 and 18 of the PRC Arbitration Law: The Great Wall of China for Foreign Arbitration Institutions, 23(2) ARB. INT'L 309, 311 (2007).

${ }^{58}$ Tao \& von Wunschheim, supra note 57, at 311.

${ }^{59}$ Chen, supra note 14, at 105-06; Mo, supra note 57, at 29; SUN \& WILLEMS, supra note 14, at 11; Tao \& von Wunschheim, supra note 57, at 312; Jane Willems, The Arbitrator's Jurisdiction at Risk: The Case of Hybrid and Asymmetrical Arbitration Agreements, in THE POWERS AND DUTIES OF AN ARBITRATOR: Liber AMICORUM Pierre A. KARRER 403, 407 (Patricia Shaugnessy \& Sherlin Tung eds., 2017); Jian Zhou, Arbitration Agreements in China: Battles on Designation of Arbitral Institution and Ad Hoc Arbitration, 23(2) J. INT'L ARB. 145, 146 (2006).

${ }^{60}$ Mo, supra note 57 , at 22.

${ }^{61}$ See Tao \& von Wunschheim, supra note 57 , at 311.

${ }^{62}$ Zhou, supra note 59, at 169.

${ }^{63}$ See Chen, supra note 14, at 89; see generally Houchih Kuo, Refusal of Taiwanese Court to Recognize Ad Hoc Arbitration: Implications and the Future of Ad Hoc Arbitration in Taiwan, ASIAN DISP. REV. 59 (2012).

${ }^{64}$ Kuo, supra note 63, at 59.
} 
earlier ${ }^{65}$ that expressly defines arbitration as any arbitration whether or not administered by a permanent arbitral institution. In light of the current case law, the distinction between ad hoc and institutional arbitration matters under Taiwan arbitration law as it stands, ${ }^{66}$ although Taiwanese scholars argue that both categories of arbitration should be permitted under the Taiwan Arbitration Act. ${ }^{67}$ This does not necessarily mean that the delimitation between these two arbitration categories as developed in other contexts can also be used in Taiwan arbitration law, because-not unlike the arbitration law of the PRC-Article 54 of the Taiwan Arbitration Act provides its own definition of the term "arbitration institution" that effectively covers only arbitral institutions whose establishment has been approved by the Taiwanese government. ${ }^{68}$

(d) Need for an Autonomous Construction of Each "Category Exclusive" Rule — Under "category exclusive" rules of arbitration law, ${ }^{69}$ the precise definition of the arbitration category (or categories) employed therein accordingly matters, because it determines whether the legal consequences provided for in such provisions are triggered. The distinction between the categories of institutional arbitration, ad hoc arbitration and conceivable other types of arbitration is therefore of legal relevance under such rules of law.

While it is tempting to conclude that this fact automatically grants relevance to the topic discussed here, a note of caution is in order: The general distinction between arbitration categories to be attempted in the following does not necessarily have to dovetail with the definition of arbitration categories used in individual provisions of arbitration law, may they be domestic or international. The reason is simple: Each of these provisions has to be construed in accordance with the rules of interpretation applicable to the respective legal norm, and these rules may well differ. Interpretation rules furthermore often look to the purpose of the respective provision, its legislative history and systematic relationship with other provisions of law, and these factors will frequently be unique to a particular "category exclusive" rule of arbitration law.

\footnotetext{
${ }^{65}$ Supra Section III.C.1.

${ }^{66}$ Kuo, supra note 63, at 60 (stresses that parties are strongly advised not to choose ad hoc arbitration in Taiwan.).

${ }^{67}$ See Chen, supra note 14, at 97 with numerous references; Kuo, supra note 63, at 61.

${ }^{68}$ Kuo, supra note 63 , at 60.

${ }^{69}$ Supra Section III.C.2.
} 


\section{Merits of a Comparative Law and Practice Perspective on Arbitration Categories}

In contrast, the present article adopts a comparative approach, looking at "borderline cases" that have been addressed under various domestic arbitration laws and institutional arbitration rules, and trying to identify a common core of principles underlying the treatment of these cases. As a result, the conclusions to be developed below are not tel quel applicable to each existing provision that distinguishes between arbitration categories, and should not be so understood.

What are then the merits of the comparative law and practice perspective followed here? In response to this well-justified question, one may refer to the traditional purposes of comparative legal research: Such research has famously been described as an "école de vérité" which extends and enriches the "supply of solutions" available, ${ }^{70}$ and offers jurists the opportunity of finding a better solution to a pertinent problem in their time and place. ${ }^{71}$ An important practical use of comparative law is its function as a tool in the construction of domestic and international legal rules, in the area of arbitration as much as elsewhere. ${ }^{72}$ As issues of construction from time to time concern the specific question tackled in the present article, its results may prove helpful to arbitrators, courts and counsel in determining where the line between ad hoc arbitration and institutional arbitration precisely runs. Last but not least, the arguments to be developed below are a modest contribution to the ongoing discussion about the theory of arbitration, ${ }^{73}$ including the alleged "institutionalization" of international commercial arbitration. $^{74}$

\section{BORDERLINE CASES-AND WHAT WE CAN LEARN FROM THEM}

As already indicated, ${ }^{75}$ the traditional ad hoc/institutional arbitration dichotomy has increasingly been challenged in recent years, and it has been pointed out that the boundaries between these established categories can become blurred. The latter phenomenon becomes apparent in "borderline cases", i.e., cases that cannot without difficulties be filed under one of the two categories. Four such borderline constellations will be investigated, in

\footnotetext{
${ }^{70}$ Ernst Zitelmann, Aufgaben und Bedeutung der Rechtsvergleichung, 5 DEUTSCHE JURISTENZEITUNG 329, 329-32 (1900).

${ }^{71}$ KONRAD ZWEIGERT \& HEIN KÖTZ, AN INTRODUCTION TO COMPARATIVE LAW 15 (3d ed. 1998).

${ }^{72}$ See Jürgen Basedow, Comparative Law and Its Clients, 62(4) AM. J. CoMP. L. 821, 839-42 (2014); ZWEIGERT \& KÖTZ, supra note 71, at 18.

${ }^{73}$ See BORN, supra note 1, at 214-17; FOUCHARD GAILLARD GOLDMAN, supra note 4, $\uparrow \uparrow$ 44-57; LEW ET AL., supra note 1, ๆ 5-1 to 5-33.

${ }^{74}$ FOUCHARD GAILLARD GOLDMAN, supra note 4, $₫ 53$.

${ }^{75}$ Supra Section II.D.
} 
order to determine what lessons can be learned from their treatment in case law and in academic discussions for the distinction between institutional and ad hoc arbitration in general.

All four constellations to be addressed below have one factor in common: They are the result of party autonomy, the fundamental principle of all arbitration that, at least in principle, also applies in institutional arbitration. ${ }^{76}$ Where the parties have exercised their autonomy in a particular manner, the traditionally clear-cut line between ad hoc and institutional arbitration blurs.

\section{A. UNCITRAL Arbitrations Involving Arbitral Institutions}

The first group of borderline cases are arbitral proceedings conducted under the UNCITRAL Arbitration Rules. The well-known set of rules was initially adopted by the United Nations Commission on International Trade Law (hereinafter "UNCITRAL") in 1976 in order to contribute to the development of harmonious international economic relations through the establishment of rules for $a d$ hoc arbitration that are acceptable in countries with different legal, social and economic systems. ${ }^{77}$ After their successful use by parties in a wide variety of circumstances covering a broad range of disputes, ${ }^{78}$ the Rules underwent a partial revision in 2010 .

As UNCITRAL itself does not administer arbitrations, ${ }^{79}$ the UNCITRAL Arbitration Rules were designed as a set of stand-alone arbitration rules not necessarily depending on institutional support. Arbitrations under the UNCITRAL Rules therefore display one of the features commonly associated with institutional arbitration ${ }^{80}$ (namely the use of preexisting arbitration rules), but not the other (the proceedings' administration by an institution). This characteristic has led to controversial discussions about the position of UNCITRAL arbitrations within the traditionally "bifocal" world of ad hoc and institutional arbitrations.

\footnotetext{
76 Andrea Carlevaris, The Bounds of Party Autonomy in Institutional Arbitration, in INTERNATIONAL ARBITRATION UNDER REVIEW: ESSAYS IN HONOUR OF JOHN BEECHEY 103, $103-$ 04 (Andrea Carlevaris et al. ed., 2015); Freyer, supra note 7, at 14; Schäfer, supra note 14, ๆ 339; MAXI SCHERER ET AL., ARBITRATING UNDER THE 2014 LCIA RULES: A USER'S GUIDE 36 (2015); SHAi WAdE ET AL., A COMMENTARY ON THE LCIA ARBITRATION RULES 2014 ๆ I-019 (2015).

${ }_{77}$ G.A. Res. 31/98 (Dec. 15, 1976).

${ }^{78}$ G.A. Res. 65/22 (Dec. 6, 2010); Sarah Grimmer, The Expanded Role of the Appointing Authority Under the UNCITRAL Arbitration Rules 2010, 28(5) J. INT'L ARB. 501, 501 (2011).

${ }^{79}$ Clyde Croft et al., A Guide to the UNCITRAL Arbitration Rules 96.1 (2013); Stephen L. Drymer, The Revised 2010 UNCITRAL Arbitration Rules: New Rules/New Roles for Designating and Appointing Authorities, 28(4) ASA Bull. 869, 871 (2010); Paolo Michele Patocchi \& Tilman Niedermaier, UNCITRAL Rules, in InSTITUTIONAL ARBITRATION, supra note 9, $1007, \uparrow 13$.

${ }^{80}$ Supra Section II.B.
} 
1. Arbitration Proceedings According to the UNCITRAL Arbitration Rules Without any Institution's Involvement - As a preliminary issue, it could be considered whether an arbitration conducted in accordance with the UNCITRAL Arbitration Rules, but without any arbitral institution being involved, is already something different than a "normal" (i.e., nonUNCITRAL Arbitration Rules) ad hoc arbitration. If this assumption was accurate, every arbitration under the UNCITRAL Arbitration Rules would constitute a "borderline case", with such arbitrations possibly forming a separate category of arbitrations. And indeed, commentators have argued in favour of such a view, seemingly because the use of preexisting arbitration rules (as notably the 1976 UNCITRAL Rules) decisively distinguishes such arbitrations from typical ad hoc arbitrations. ${ }^{81}$

It is correct that the UNCITRAL Arbitration Rules were designed to remedy the lack of established procedures that can be a disadvantage when proceeding ad hoc, ${ }^{82}$ and that their rules of procedure are precise enough to preclude the need for any subsidiary recourse to national arbitration laws. ${ }^{83}$ It is nevertheless clear that the UNCITRAL Rules were developed for use in ad hoc arbitrations, ${ }^{84}$ and there is no indication that the drafters intended the Rules' off-the-shelf provisions to change the ad hoc character of resulting proceedings. In his commentary on the 1976 UNCITRAL Arbitration Rules, Pieter Sanders, the principal drafter and "father" of the Rules, specifically stressed that the UNCITRAL Rules "do not compete with institutional arbitration since, unlike the arbitration rules of every arbitral institution, the UNCITRAL Rules do not provide for the administration of the arbitration", 85 and that accordingly "arbitration under the UNCITRAL Arbitration Rules cannot be regarded as institutional, administered arbitration". ${ }^{86}$ Their historical background thus clarifies that the UNCITRAL Arbitration Rules merely ease the exercise of procedural party autonomy by providing expertly-designed default rules to govern the arbitration proceedings, in place of the lex arbitri's otherwise applicable default provisions. However, they do not change the nature of UNCITRAL arbitrations as ad hoc arbitrations. ${ }^{87}$

What does this discussion teach us about the distinction between arbitration categories? It clarifies that the use of preexisting arbitration

\footnotetext{
${ }^{81}$ In this sense see SCHLOSSER, supra note 14, 179.

${ }^{82}$ Freyer, supra note 7 , at 23.

${ }^{83}$ FOUCHARD GAILLARD GOLDMAN, supra note 4, ๆ 201.

${ }^{84}$ See Aksen, supra note 1, at 11; BORN, supra note 1, at 173; FOUCHARD GAILlARD GOLDMAN, supra note 4, ๆ 253; Slate, supra note 7, at 53.

${ }^{85}$ Sanders, supra note 17, ๆ 2.2 .

${ }^{86} I d$. $\mid 2.4$.

${ }^{87}$ Freyer, supra note 7, at 23; Patocchi \& Niedermaier, supra note 79, 913 ; Perales Viscasillas, supra note 8, at 38-39; Schlaepfer \& Petti, supra note 1, at 14; TWEEDDALE \& TWEEDDALE, supra note 6 , 3.84 ; probably see also Chen, supra note 14 , at 92 .
} 
rules alone does not make an arbitration "institutional", 88 although the use of arbitration rules not tailor-made for a particular proceeding is one of the usual components in the prevailing definitions of institutional arbitration. The application of the UNCITRAL Arbitration Rules alone therefore leaves an arbitration's ad hoc character unaffected, without turning it into a third ("hybrid") type of arbitration.

2. Arbitration Proceedings According to the UNCITRAL Arbitration Rules with an Institution Acting as Appointing Authority - More frequently, the role of the appointing authority under the UNCITRAL Arbitration Rules has been the focus of suggestions to treat certain proceedings under the UNCITRAL Rules as a special category of arbitrations.

(a) Appointing Authorities Under the 1976 UNCITRAL Arbitration Rules - Already the 1976 UNCITRAL Arbitration Rules provided for an "appointing authority" to be agreed upon by the parties, and for the Secretary-General of the Permanent Court of Arbitration at The Hague to designate an appointing authority if the parties have not so agreed. Under the 1976 UNCITRAL Rules, an appointing authority had the task to appoint arbitrator(s) in case parties or party-appointed arbitrators had failed to make a necessary appointment (Articles 6-8); in addition, it decided on challenges of arbitrators (Article 12). The 2010 UNCITRAL Arbitration Rules maintained these tasks of appointing authorities (in Articles 6, 8-10, 13(4) and 14(2)), but added further tasks to be addressed below. ${ }^{89}$

(b) Arbitration Institutions Acting as Appointing Authority - Under both the 1976 and the 2010 UNCITRAL Arbitration Rules, arbitral institutions can be agreed upon or be designated as appointing authority. ${ }^{90}$ Such a possibility, while not expressly addressed in the Rules' text, had already been foreseen by Pieter Sanders soon after the 1976 UNCITRAL Arbitration Rules were adopted. ${ }^{91}$ Although most important arbitral institutions were at first apparently reluctant to act as appointing authority, ${ }^{92}$ this practice soon became more and more common. Reacting to this development, UNCITRAL issued a set of recommendations to assist arbitral institutions with regard to arbitrations under the UNCITRAL Arbitration Rules. ${ }^{93}$ Today, e.g., ICC, the LCIA, the American Arbitration

\footnotetext{
${ }^{88}$ GERBAY, supra note 32 , at 13.

${ }^{89}$ Infra Section IV.A.3.(a).

${ }^{90}$ BORN, supra note 1 , at 1706; CARBONNEAU, supra note 4, at 501; Patocchi \& Niedermaier, supra note 79, 19; Perales Viscasillas, supra note 8, at 41; Schlaepfer \& Petti, supra note 1, at 18; WIDDASCHECK, supra note 9, at 30; Willems, supra note 59, at 407.

${ }^{91}$ Sanders, supra note 17, ๆ 2.4.

${ }^{92}$ SCHLOSSER, supra note 14, $₫ 182$.

${ }^{93}$ Recommendations to Assist Arbitral Institutions and Other Interested Bodies with Regard to Arbitrations Under the UNCITRAL Arbitration Rules Adopted at the Fifteenth Session of the Commission, 13 YEARBOOK (UNCITRAL) 420 (1982) (on the 1976 UNCITRAL Arbitration
} 
Association (hereinafter "AAA"), the Arbitration Institute of the Stockholm Chamber of Commerce (hereinafter "SCC"), the German Institution of Arbitration (DIS), the Hong Kong International Arbitration Centre (hereinafter "HKIAC"), the Permanent Court of Arbitration (hereinafter "PCA") and various other institutions all expressly offer to act as appointing authority under the UNCITRAL Rules. ${ }^{94}$ Some of these arbitral institutions have even adopted specific rules governing this task, as e.g. the ICC in form of its "Rules of ICC as Appointing Authority in UNCITRAL or Other Ad Hoc Arbitration Proceedings" of Jan. 1, 2004, ${ }^{95}$ the AAA in form of its "Procedures for Cases under the UNCITRAL Arbitration Rules" as amended and effective on Sept. 15, 2005 or the SCC with its "Procedures and Services under the UNCITRAL Arbitration Rules".

In a number of jurisdictions, arbitral institutions furthermore not only act in this function when parties have so agreed, but are designated as appointing authority by law in the local lex arbitri. Such jurisdictions mostly did so in implementing Article 6 of the 1985/2006 UNCITRAL Model Law, choosing to name a national arbitration institution as "authority for certain functions of arbitration assistance and supervision", 96 instead of State courts that perform such functions in other jurisdictions. ${ }^{97}$ Examples are inter alia the arbitration laws of Australia (designating the Australian Centre for International Commercial Arbitration), ${ }^{98}$ of Hong Kong (designating the HKIAC), ${ }^{99}$ of Malaysia (designating the Director of the Kuala Lumpur Regional Centre for Arbitration) ${ }^{100}$ and of Singapore (designating the Chairman of the Singapore (designating the Chairman of the Singapore International Arbitration Centre). ${ }^{101}$

Rules); Note by the Secretariat on Settlement of Commercial Disputes: Recommendations to Assist Arbitral Institutions and Other Interested Bodies with Regard to Arbitration Under the UNCITRAL Arbitration Rules, as Revised in 2010, 43 YEARBOOK (UNCITRAL) 251 (2012) (on the 2010 UNCITRAL Arbitration Rules).

${ }^{94}$ See Fouchard GaILlaRd GoldMAN, supra note 4, ๆ 202; LEW ET AL., supra note 1, ๆ 3-12.

${ }^{95}$ Jan Heiner Nedden \& Axel Benjamin Herzberg, Art.1/Anh.I, II ICC-SchO, in ICC-SCHO/DISSCHO: PRAXISKOMMENTAR ZU DEN SCHIEDSGERICHTSORDNUNGEN, supra note $1,11, \boldsymbol{\uparrow} 10$.

${ }^{96}$ UNCITRAL Model Law, supra note 49, art. 6.

${ }^{97}$ Note that under Article 6 of the UNCITRAL Model Law, non-judicial authorities like arbitral institutions may only be designated to perform functions in relating to the appointment of arbitrators (Article 11 of the Model Law), to challenges of arbitrators (Article 13 of the Model Law) and to the termination of their mandate (Article 14 of the Model Law). In contrast, decisions on the jurisdiction of the arbitral tribunal (Article 16(3) of the Model Law) and on applications for setting aside the award (Article 34(2) of the Model Law) remain in any case reserved for State courts; see Howard M. Holtzmann \& Joseph E. NeuHaus, A Guide to the UNCITRAL MODEL LAW ON INTERNATIONAL COMMERCIAL ARBITRATION: LEGISLATIVE HiSTORY AND COMMENTARY 239 (1989).

${ }_{98}$ International Arbitration Regulations 2011 (Cth) s 4 (Austl.).

${ }^{99}$ Arbitration Ordinance, (2014) Cap. 609, § 13 (H.K.).

${ }^{100}$ Arbitration Act 2005, sec. 13 (Malay.).

${ }^{101}$ International Arbitration Act 2002, c. 143A, sec. 8 (Sing.). 
(c) Effect on the Categorization of an Arbitration? - The role of arbitral institutions as appointing authority under the UNCITRAL Arbitration Rules, a set of rules originally designed for ad hoc arbitrations, ${ }^{102}$ begs the question whether their involvement gives such UNCITRAL arbitrations a more institutional character than "normal" ad hoc arbitrations.

A number of commentators have indeed argued in favour of such an effect on the categorization of UNCITRAL arbitrations, although the approaches vary: Some authors regard all UNCITRAL arbitrations as not ad hoc arbitrations proper, but rather a "hybrid system"103 or a cross-breed lying somewhere between ad hoc arbitration and institutional arbitration, ${ }^{104}$ irrespective of the person chosen as appointing authority being a arbitral institution or not. For them, the UNCITRAL Arbitration Rules' use of an appointing authority alone suffices to make UNCITRAL arbitrations different from ad hoc arbitrations proper. ${ }^{105}$ Other authors draw the latter conclusion only where an arbitration provides for resort to be had to an arbitral institution as appointing authority, rendering (only) such arbitrations a "hybrid model". 106

However, it is submitted that the presence of an appointing authority does not deprive an arbitration under the UNCITRAL Arbitration Rules of its character as ad hoc arbitration. ${ }^{107}$ This is primarily due to the fact that the role of an appointing authority is foreseen in most domestic arbitration laws today, not the least as a result of the 1985 UNCITRAL Model Law providing for a court or other authority for certain functions of arbitration assistance and supervision (Articles 6, 11(3), 11(4), 13(3), 14, 16(3) and 34(2) of the UNCITRAL Model Law). If the mere involvement of a third party potentially fulfilling the role of an appointing authority would render an arbitration a "hybrid" proceeding, this category would encompass the vast majority of arbitrations that have traditionally been regarded as ad hoc. For the same reason, an arbitral institution acting as appointing authority does not make the arbitration "institutional". This becomes particularly obvious when considering that in some jurisdictions, as mentioned earlier, ${ }^{108}$ arbitral institutions have been designated as statutory appointing authorities: If this role alone would affect the categorization of arbitrations

\footnotetext{
${ }^{102}$ Supra Section II.A.1.

${ }^{103}$ ThOMAs Webster, HANDBOOK OF UNCITRAL ARBitration $\uparrow \uparrow$ 0-51, 6-9 (2010).

${ }^{104}$ Philippe Fouchard, Les Travaux de la C.N.U.D.C.I.: Le Règlement d'arbitrage, JouRNAL DU DROIT INTERNATIONAL 816, 829 (1979); see also Patocchi \& Niedermaier, supra note 79, ๆ 17.

${ }^{105}$ WIDDASCHECK, supra note 9 , at 13 (regards it as an "institutionalization" of the arbitral proceedings).

${ }^{106}$ WAINCYMER, supra note 26 , at 93.16 .

${ }^{107}$ See BORN, supra note 1, at 1706 ("non-institutional arbitration”); Perales Viscasillas, supra note 8, at 49 ("still an ad hoc arbitration, and it is not a third type of arbitration"); SCHLOSSER, supra note 14, at 599.

${ }^{108}$ Supra Section IV.A.2.b.
} 
concerned, there would be no more ad hoc arbitrations in Australia, Hong Kong, Malaysia or Singapore.

The drafting history of the 1976 UNCITRAL Arbitration Rules supports the position taken here, although its message is admittedly mixed. On one hand, the drafters were of the opinion that UNCITRAL arbitrations were not institutional arbitrations (as already discussed ${ }^{109}$ ), and seemingly so in spite of the role they had given to appointing authorities in the Rules. ${ }^{110}$ On the other hand, the rather complicated procedure under the 1976 UNCITRAL Arbitration Rules for having an arbitrator appointed where the parties have not agreed on an appointing authority in their contract - with the Secretary General of the PCA at the Hague merely designating an appointing authority, but not appointing the arbitrator himself 111 - was explained as "the only solution UNCITRAL could find without making its arbitration a fully administered, institutional arbitration". ${ }^{112}$ The latter remark could be read as an indication that direct appointments of arbitrators by the Secretary General of the PCA (or any other institution) would have been viewed as making such UNCITRAL arbitrations "institutional" in nature - an assessment that would seem at least doubtful under today's arbitration law and practice.

Finally, case law has similarly found "a clear distinction" between an arbitral institution which administers an arbitration and an arbitral institution designated as an appointing authority for the purpose of appointing the arbitral tribunal. ${ }^{11}$

(d) Lessons Learned for the Distinction Between Arbitration Categories - The present discussion has confirmed that the involvement of an appointing authority in an arbitration does not make the arbitration institutional. This is true even if the parties have agreed on an arbitral institution to act as appointing authority, and remains true if they have furthermore agreed on a pre-existing set of rules (as the UNCITRAL Arbitration Rules) to govern the proceeding, as long as these arbitration rules are not the institutional rules issued by the arbitral institution involved. On a more general level, it can therefore be said that the involvement of an appointing authority eventually remains without any effect for the categorization of arbitrations.

3. Arbitration Proceedings According to the UNCITRAL Arbitration Rules Administered by an Institution - A third and final variation of this

\footnotetext{
${ }^{109}$ Supra Section IV.A.1.

${ }^{110}$ See Sanders, supra note 17, at 9 2.2, 2.4.

${ }^{111}$ United Nations Commission on International Trade Law (UNCITRAL) Arbitration Rules, art. 6(2) (1976).

${ }^{112}$ Sanders, supra note 17 , at 96.2 .

${ }^{113}$ Subway Systems Australia Pty. Ltd. v Aaron Ireland and Lynette Ireland [2013] VSC 550, ๆ 51 (Austl.); similarly see BORN, supra note 1, at 1703; SUTTON ET AL., supra note 21, at $92-062$; Nedden \& Herzberg, supra note 95, at $₫ 10$.
} 
discussion has emerged relatively recently. Its source is the expansion of administrative tasks that may be allocated to an arbitral institution under the 2010 UNCITRAL Arbitration Rules, due to changes introduced into the UNCITRAL Rules in their 2010 revision.

(a) Expansion of the Appointing Authority's Role Under the 2010 UNCITRAL Arbitration Rules - As a result of these changes, an arbitral institution acting as appointing authority may now be requested, under certain circumstances, e.g. to constitute the arbitral tribunal (and in doing so, revoke any appointment already made and appoint or reappoint each of the arbitrators); to determine whether a party may be deprived of its right to appoint a substitute arbitrator and authorize a truncated tribunal to proceed and issue an award; and to revise - with binding effect - a tribunal's decision on its fees. ${ }^{114}$ The expansion of the appointing authority's role under the 2010 UNCITRAL Arbitration Rules has therefore been described as "significant", not only in regard of the number of tasks assigned to it, but also in view of the increased gravity of those tasks. ${ }^{115}$

A related scenario arises when parties provide in their arbitration agreement for the arbitration to be held in accordance with the 1976 or 2010 UNCITRAL Arbitration Rules, but to be "administered" by an arbitral institution. ${ }^{116}$ It has been held that the administration of an arbitration involves more than just acting as an appointing authority ${ }^{117}$ by additionally including some assistance provided by the administering institution throughout the arbitral proceeding. While a party agreement on an "administered" UNCITRAL arbitration may indeed suggest an institutional involvement that extends beyond an appointing authority's role, it remains a matter of interpretation what the desired administration includes in a particular case.

(b) Effect on the Categorization of an Arbitration? - Against this background, some commentators have argued that arbitrations under the 2010 UNCITRAL Arbitration Rules no longer constitute ad hoc arbitrations, but rather administered arbitrations with the UNCITRAL Arbitration Rules as rules of the arbitration, ${ }^{118}$ or that UNCITRAL arbitrations now at least "potentially" belong to the institutional arbitration

\footnotetext{
${ }^{114}$ Grimmer, supra note 78, at 501, with a detailed discussion of the respective UNCITRAL Rules changes at 504-16.

${ }^{115}$ Drymer, supra note 79 , at 877 ; Grimmer, supra note 78 , at 502; see also CROFT ET AL., supra note 79, at 6.3; WIDDASCHECK, supra note 9, at 79-80.

${ }^{116}$ See Subway Systems Australia Pty. Ltd. v Aaron Ireland and Lynette Ireland [2013] VSC 550, I 43 (Austl.) ("The arbitration will be held in accordance with the United Nations Commission on International Trade Regulations and Law (UNCITRAL) Arbitration Rules administered by an arbitration association, such as the American Arbitration Association or the Institute of Arbitrators or Mediators Australia, at a hearing to be held in Queensland.").

${ }^{117} I d$. at 49; PAUL FriedLAND, ARBITRATION CLAUSES FOR INTERNATIONAL CONTRACTS 37 (2d ed. 2007); Perales Viscasillas, supra note 8, at 45.

${ }^{118}$ Perales Viscasillas, supra note 8, at 62 (“[N]ot an ad hoc arbitration”).
} 
category. ${ }^{119}$ Occasionally, the 2010 UNCITRAL Arbitration Rules have been characterized as "semi-institutional". ${ }^{120}$ Yet other commentators argue that the expansion of the appointing authority's role has led to the 2010 UNCITRAL Arbitration Rules resembling institutional rules more than the 1976 UNCITRAL Rules, with UNCITRAL arbitrations nonetheless stopping short of being institutional. ${ }^{121}$ In the related cases of arbitration agreements providing an UNCITRAL arbitration 'administered' by an arbitral institution, it has been held that such an arbitration no longer qualifies as ad hoc. ${ }^{122}$

However, the more convincing view is that the appointing authorities' expanded role under the 2010 UNCITRAL Rules has not changed the character of UNCITRAL arbitrations, which remain non-institutional. ${ }^{123}$ This is first of all due to the lack of any indication that the drafters of the 2010 rules revision intended such a change - on the contrary, it was their declared goal to "maintain the original structure and spirit of the UNCITRAL Arbitration Rules". ${ }^{124}$ Consistent with this aim, the additional tasks assigned to the appointing authority mainly deal with exceptional circumstances, ${ }^{125}$ barring the added power under Article 7(2) to submit a case to a sole arbitrator. Arbitral institutions also continue to distinguish between the role of an appointing authority under the 2010 UNCITRAL Arbitration Rules and the administration of arbitrations under the UNCITRAL Rules: For example, the ICC will act as an appointing authority, but-unlike some other arbitral institutions-it will not administer arbitrations under the UNCITRAL (or other) Rules. ${ }^{126}$

It is a different and more complex question whether the possible case administration by an arbitral institution foreseen under the 2010 UNCITRAL Rules may change an arbitration's character from ad hoc to something different, if the administration is sufficiently broad and intensive. To this issue we turn next.

(c) Minimum Degree of Administration Required for Effect on the Categorization of an Arbitration? - Some authors indeed regard an

\footnotetext{
${ }^{119}$ GERBAY, supra note 32, at 14.

${ }^{120}$ WIDDASCHECK, supra note 9 , at 85.

${ }^{121}$ Grimmer, supra note 78, at 516; Drymer, supra note 79, at 877 (the 2010 Rules "institutionalise, to a certain degree, UNCITRAL arbitration").

${ }^{122}$ Subway Systems Australia Pty. Ltd. v Aaron Ireland and Lynette Ireland [2013] VSC 550, 949 (Austl.).

${ }^{123}$ See Drymer, supra note 79, at 875-76 ("[T] he UNCITRAL Rules are not institutional rules, and UNCITRAL arbitration is not institutional.").

${ }^{124}$ U.N. Secretary-General, Settlement of Commercial Disputes: Revision of the UNCITRAL Arbitration Rules, 2, U.N. Doc. A/CN.9/703 (Mar. 5, 2010); see also U.N. GAOR, 61 th Sess., at ๑ 184, U.N. Doc. A/61/17 (July 14, 2006).

${ }^{125}$ Grimmer, supra note 78 , at 516.

${ }^{126}$ Yves Derains \& ERIC A. SCHWARtZ, A Guide to the ICC Rules of ARbitration 10 (2d ed. 2005).
} 
UNCITRAL arbitration's administration by an arbitral institution alone as insufficient to render the arbitration "institutional", but in addition look to the amount and type of administrative services offered by the institution. In doing so, they require a certain minimum degree of administration as a prerequisite for administered UNCITRAL arbitrations no longer being ad hoc arbitrations. ${ }^{127}$

The question then immediately becomes what degree of administration is supposed to change an arbitration's category from ad hoc to institutional or to a third, intermediate category. The answer is difficult because the administrative services offered differ significantly between arbitral institutions, both in scope and in content. ${ }^{128}$ A leading international textbook ${ }^{129}$ distinguishes between wholly administered and semiadministered arbitrations: In a wholly administered arbitration, the arbitral institution provides a full service to the arbitral tribunal (an example being ICSID), while in a semi-administered arbitration the institution collects the initial advance on costs from the parties, appoints the arbitral tribunal, and then leaves it to the arbitral tribunal to communicate with the parties, arrange meetings and hearings, and so forth (an example being arbitrations conducted in England under the Chartered Institute of Arbitrators' Rules). ${ }^{130}$ But this rough distinction is of limited use when it comes to capturing the various approaches of arbitral institutions to case administration and their effect, if any, on the categorization of arbitrations. The following examples are indicative of the uncertainties:

1. The London Maritime Arbitrators Association (hereinafter "LMAA") only makes default appointments of arbitrators as an appointing authority without providing any other services, ${ }^{131}$ but has nevertheless been described as an arbitral "institution". ${ }^{132}$ In spite of its institutional characterization, arbitration in accordance with the terms of the LMAA is mostly considered ad hoc arbitration. ${ }^{133}$

2. Similarly, the very limited support offered by the Federation of Oils Sees and Fats Associations (hereinafter "FOSFA") to parties conducting arbitration under FOSFA's arbitration rules supposedly falls short of what is conventionally considered as institutional

\footnotetext{
${ }^{127}$ GERBAY, supra note 32 , at 14 ; Viscasillas, supra note 8 , at 74 ; see also WIDDASCHECK, supra note 9 , at 59-60.

${ }^{128}$ SUTTON ET AL., supra note 21, at \3-052; Schäfer, supra note 14, at 9310 ; Schlaepfer \& Petti, supra note 1, at 22; Schütze, supra note 9, at 9 ๆ 9-10; Slate, supra note 7, at 47; Timar, supra note 5, at 119-20; WIDDASCHECK, supra note 9, at 15; WOLF, supra note 24, at 16-35.

${ }^{129}$ BLACKABY ET AL., supra note 4, at 91.146 n.157.

${ }^{130} \mathrm{Id}$.

${ }^{131}$ WADE ET AL., supra note 76, at $\uparrow$ I-009.

${ }^{132}$ Bertie Vigras, The Role of Institutions in Arbitration, in HANDBOOK OF ARBITRATION PRACTICE 461 (Ronald Bernstein \& Derek Wood et al. eds., 2d ed. 1993).

${ }^{133}$ Bruce Harris, London Maritime Arbitration, reprinted in 77 ARBITRATION 116, 122 (2011); GERBAY, supra note 32, at 6 .
} 
arbitration, ${ }^{134}$ although it remains far from clear what that alleged conventional standard is. FOSFA arbitration is in general regarded as ad hoc, ${ }^{135}$ which is remarkable given that FOSFA even operates and maintains an appeal panel. ${ }^{136}$ Only occasionally has FOSFA arbitration been viewed as "institutionalized". 137

3. In arbitration according to the long-standing rules of the so-called Hamburg friendly arbitration (Hamburger freundschaftliche Arbitrage), no administration services are offered, although the Hamburg Chamber of Commerce potentially acts as the appointing authority. Due to the lack of administration, Hamburg friendly arbitration is predominantly categorized as ad hoc arbitration. ${ }^{138}$ In contrast, the German Federal Supreme Court qualified the Hamburger freundschaftliche Arbitrage as a permanent arbitral institution (and thereby the related arbitrations supposedly as institutional ${ }^{139}$ ), although the degree of administration played no role in this context; instead, the court regarded the use of the institution's own arbitration rules as the decisive point. ${ }^{140}$

4. Among the major international arbitral institutions, the LCIA is often characterized by its supposed "light touch" approach to case administration, ${ }^{141}$ although its administrative involvement appears less light when compared with that of the LMAA, the FOSFA or the Hamburg friendly arbitration. When instead the ICC is used as comparative standard, LCIA arbitration may well be described as "less 'institutionalized' and interventionist", ${ }^{142}$ or even as occupying an

\footnotetext{
${ }^{134}$ GERBAY, supra note 32 , at 7.

${ }^{135} \mathrm{Id}$. at 7; ROBERT MERKIN, ARBITRATION LAW 36 (3d ed. 2004).

${ }^{136}$ See Brian Chapman, FOSFA International Arbitration, 2(4) ARB. INT'L 323, 330-31(1986).

${ }^{137}$ Jacques Covo, Commodities, Arbitrations and Equitable Considerations, 9(1) ARB. INT'L 57, 60 (1993).

${ }^{138}$ Mike Oliver Korte, Die Hamburger Freundschaftliche Arbitrage - Ein Überblick Anlässlich des 100-jährigen Jubiläums des $\$ 20$ Platzusancen für den Hamburgischen Warenhandel, in ZEITSCHRIFT FÜR SCHIEDSVERFAHREN 240, 241 (2004); ROLF A. SCHÜTZE ET AL., HANDBUCH DES SCHIEDSVERFAHRENS \792 (2d ed. 1990); Karl Heinz Schwab \& Gerhard Walter, Kapitel 41. Grundlagen des Internationalen Schiedsverfahrens, in SCHIEDSGERICHTSBARKEIT 916 (7th ed. 2005); Hanspeter Vogel, Institutionalisierte Schiedsgerichtsbarkeit, in RECHT UND JURISTEN IN HAMBURG 22 (1994).

139 In this sense, Karl Heinz Schwab \& Gerhard Walter, Kapitel 41. Grundlagen des Internationalen Schiedsverfahrens, in SCHIEDSGERICHTSBARKEIT 16 (Schwab \& Walter et al. eds., 2000).

${ }^{140}$ Bundesgerichtshof [BGH] [Federal Court of Justice] Dec. 2, 1982, NeUE JURISTISCHE WOCHENSCHRIFT [NJW] 1268, 1983 (Ger.).

${ }_{141}$ Adrian Winstanley, Review of the London Court of International Arbitration, in INTERNATIONAL COMMERCIAL ARBITRATION PRACTICE: 21ST CENTURY PERSPECTIVES 3 (Horacio Grigera Naón ed., 2010). For a sceptical view of this assessment see SCHERER ET AL., supra note 76 , at 24 .

${ }^{142}$ Lew et al., supra note 32, at 918.20 ; see also SUTTON ET AL., supra note 21, at 9 3-053; in more detail Sabine Konrad \& Robert Hunter, LCIA Rules, in InSTITUTIONAL ARBITRATION, supra
} 
historical position "halfway between full institutional arbitration and ad hoc forms of arbitration". ${ }^{143}$ In any case and in spite of their divergent administrative styles, both ICC and LCIA arbitration are generally regarded as institutional. ${ }^{144}$

These examples - and various others could be mentioneddemonstrate the difficulty of classifying existing approaches to case administration, and how subjective (and sometimes random) categorizations derived from such classifications can be. A related issue is the difficulty of defining the degree of administration that marks the line between ad hoc and institutional arbitration in a clear and workable manner, given the need for foreseeable criteria and the variety of administrative services offered by different institutions. Some basic assumptions are intuitively convincing, as e.g., simple administrative services not being sufficient to render an arbitration "institutional", because mere office centres would otherwise qualify as arbitral institutions. ${ }^{145}$ But beyond this point, both generally acceptable and workable criteria are almost impossible to define. For example, suggested distinctions like the one between partial administrative services (resulting in ad hoc arbitration) ${ }^{146}$ and a fully administered arbitration under the 2010 UNCITRAL Rules (being an institutional arbitration) ${ }^{147}$ leave practitioners with significant uncertainty, given the differences between the "full" services as offered by different arbitral institutions.

In essence, the lack of agreed criteria therefore render the "degree" of case administration an unconvincing guidepost for the delimitation of arbitration categories. Against this background, it is submitted that neither the use of administrative services as such ${ }^{148}$ nor the breadth of such administration should be decisive in this respect. Accordingly, arbitrations under the 2010 UNCITRAL Arbitration Rules may on occasion be "administered" ad hoc arbitrations, but are ad hoc arbitrations nonetheless. 149

(d) Lessons Learned for the Distinction Between Arbitration Categories - The present discussion has shown that the additional tasks carried out by an appointing authority under the 2010 UNCITRAL Arbitration Rules do not turn UNCITRAL arbitrations into institutional

note 9,413 , $\uparrow$ 67-73. But see McIlWRATH \& SAVAGE, supra note 1, at $91-100$, who argue that in practical terms, the LCIA does not differ substantially from the ICC in many respects.

${ }^{143}$ V.V. Veeder, The New 1998 LCIA Rules, in YEARBOOK COMMERCIAL ARBITRATION 1998: VOLUME XXIII 366, 366 (Albert Jan van den Berg ed., 1998).

${ }^{144}$ Lalive, supra note 1, at 665; SUTTON ET AL., supra note 21, at 9 3-053 (on both ICC and LCIA arbitration); WADE ET AL., supra note 76, at I-009 (on LCIA arbitration).

${ }^{145}$ Perales Viscasillas, supra note 8 , at 46.

${ }^{146} \mathrm{Id}$. at 74 .

${ }^{147}$ Perales Viscasillas, supra note 8, at 72.

${ }^{148}$ Lalive, supra note 1, at 665; Zhou, supra note 59, at 146.

${ }^{149}$ Willems, supra note 59, at 408-09. 
arbitrations. ${ }^{150}$ The same is true for the administration of an arbitration by an arbitral institution where the institution does not act under its own institutional rules, but based on a clause in the arbitration agreement. ${ }^{151}$ The underlying ratio in both constellations is that the degree of institutional administrative services provided is too vague and uncertain a criterion to distinguish between arbitration categories, given that the services offered vary so much from institution to institution.

\section{B. Parties' Choice of Institutional Rules, but Not of the Issuing Institution (and Vice Versa)}

The textbook definitions of the term "institutional arbitration" presented earlier ${ }^{152}$ demonstrated that almost every definition attempt combines two components, namely the arbitral institution and arbitration rules issued by that institution. What effect, if any, does it then have for an arbitration's categorization if the parties have only chosen one of these two components in their arbitration agreement?

1. Choice of Institutional Rules Only - Cases in which arbitration agreements refer only to an institution's arbitration rules are particularly frequent, not the least because the standard arbitration clauses of most institutions only speak of the respective rules, but not of the issuing institution itself. Examples are the LCIA's recommended clause ("Any dispute ... shall be referred to and finally resolved by arbitration under the LCIA Rules, .....") or the Standard ICC Arbitration Clause ("All disputes . . . shall be finally settled under the Rules of Arbitration of the International Chamber of Commerce ....."), among many others. In order to avoid any uncertainty about the role of the rules-issuing institution in these cases, some institutional rules expressly provide that a choice of the rules is deemed to be also a choice of the institution. For example, Article 6(2) of the 2017 ICC Rules states that "[b]y agreeing to arbitration under the Rules, the parties have accepted that the arbitration shall be administered by the [ICC] Court." But the same result could arguably be reached without an explicit provision through a reasonable construction of the arbitration agreement. ${ }^{153}$ An interpretation of such arbitration agreements thereby

\footnotetext{
${ }^{150}$ Supra Section IV.A.3.b.

${ }^{151}$ Supra Section IV.A.3.(c).

${ }^{152}$ Supra Section II.B.

${ }^{153}$ Insigma v. Alstom, supra note 2, ๆ 33; York Research Corp. v. Landgarten, 927 F.2d 119, 123 (2d Cir. 1991) (arbitration clause that any dispute "shall be determined and settled by binding arbitration in New York pursuant to [the AAA's rules]" is an agreement that "the AAA should administer the arbitration process and apply its Commercial Arbitration Rules"); Prostyakov v. Masco Corp., 513 F.3d 716, 724 (7th Cir. 2008) (parties "did, in fact, submit to AAA participation by agreeing that the arbitration would be governed by AAA rules"); Zhou, supra note 59, at 145. A different conclusion was reached by the Supreme Court of New York in Nachmani v. By Design, LLC, 901 N.Y.S.2d 838, 839 (1st Dep't. 2010), where an arbitration clause's reference to
} 
usually guarantees that both traditional components of an institutional arbitration are present.

The situation can be more difficult where legal provisions impose particular requirements on the choice of an arbitral institution in arbitration agreements. The most prominent example is Article 16(2) of the Arbitration Law of the Peoples' Republic of China and its mention of "[ $t$ ]he arbitration commission chosen" as a necessary content of any valid arbitration clause. ${ }^{154}$ Not surprisingly, the model clause used by the China International Economic and Trade Arbitration Commission (CIETAC) therefore explicitly refers to both the institution and its rules ("Any dispute arising from or in connection with this Contract shall be submitted to China International Economic and Trade Arbitration Commission for arbitration which shall be conducted in accordance with the Commission's arbitration rules ... ."). And for parties wishing to have an ICC Arbitration in Mainland China, the ICC has supplemented its standard arbitration clause for this purpose, recommending to also include an explicit reference to the institution ("All disputes . . . shall be submitted to the International Court of Arbitration of the International Chamber of Commerce and shall be finally settled under the Rules of Arbitration of the International Chamber of Commerce .....”. In case an arbitration agreement refers exclusively to institutional arbitration rules, the PRC's Supreme People's Court has described its effect under the Chinese lex arbitri as follows:

Where the arbitration agreement only agrees upon the applicable arbitration rules, it shall be deemed that no arbitration institution has been agreed upon, except where the parties concerned have reached a supplementary agreement, or where the arbitration institution can be determined according to the arbitration rules that have been agreed on. ${ }^{155}$

The latter caveat - "except where ... the arbitration institution can be determined according to the arbitration rules that have been agreed on"was one of the reasons for the introduction of Article 6(2) of the 2012 and 2017 ICC Rules, the provision mentioned earlier. ${ }^{156}$

\footnotetext{
arbitration "in accordance with AAA Commercial Arbitration Rules' was interpreted as only a 'choice of law . . . clause' and not an agreement that the arbitration be administered by the AAA"; see the critical remarks in BORN, supra note 1, at 833 ("That conclusion, and its reasoning, is plainly wrong".).

${ }^{154}$ Supra Section III.C.2.(b).

${ }^{155}$ Zuigao Renmin Fayuan Kuanyu Shihyung Zhunghua Renmin Guongheguo Chungtsaifa Jogan Wenti de Chiehhsieh [Interpretation of the Supreme People's Court concerning Some Issues on Application of the Arbitration Law of the People's Republic of China] art. 4 (Ch.).

${ }^{156}$ JASON Fry ET AL., THE SECRETARIAT’s GUIDE TO ICC ARBITRATION $\uparrow 3-4$ (2012).
} 
Nevertheless, certain cases remain in which an arbitration agreement referring only to institutional rules cannot be interpreted as also selecting the issuing institution. One example are cases in which the parties have explicitly agreed on their arbitration to be conducted ad hoc, but under institutional rules ${ }^{157}$ - a rare case, and an approach that has rightfully been discouraged. ${ }^{158}$ Another example are cases in which the arbitration agreement calls for the arbitrator to be appointed by one institution and provides that this arbitrator must then conduct the proceedings in accordance with the rules of another institution. ${ }^{159}$ In neither of such situations, the mere agreement on institutional arbitration rules affect the arbitration's ad hoc nature, ${ }^{160}$ indicating that the use of institutional rules alone does not make an arbitration "institutional".

2. Choice of Institution Only — The reverse constellation-party agreements that refer only to an arbitral institution, but not to its rulessimilarly raises the question which category the resulting arbitration belongs to. Some standard arbitration clauses are framed in this way, as for example the clause recommended by the Court of Arbitration of the Hamburg Chamber of Commerce ("Any dispute . . . shall be finally settled by the Court of Arbitration of the Hamburg Chamber of Commerce . . ..”).

Similar to what was described a moment ago, ${ }^{161}$ a reasonable construction of such "institution only" clauses will usually reveal that the parties intended the arbitral rules of that institution to apply. ${ }^{162}$ Article IV(1)(a) of the 1961 Geneva Convention even contains a legal assumption to his end. After confirming under the heading "Organization of the arbitration" that the parties to an arbitration agreement are free to submit their disputes to a permanent arbitral institution, Article IV(1)(a) provides that "in this case, the arbitration proceedings shall be held in conformity with the rules of the said institution". Whenever either the interpretation of the arbitration clause or the application of Article IV(1)(a) of the 1961 Geneva Convention thus supplements an "institution only" clause by adding the institution's rules of arbitration, the arbitration will be

\footnotetext{
${ }^{157}$ TweEdDale \& TweEdDale, supra note 6 , at $\$ 3.02$; Heiko A. Haller, $\$ 24$ DIS-SchO, in ICCSCHO/DIS-SCHO: PRAXISKOMMENTAR ZU DEN SCHIEDSGERICHTSORDNUNGEN, supra note 1, 806, - 24.

${ }^{158}$ BLACKABY ET AL., supra note 4, ๆ 1.144 n.154; Haller, supra note 157, 806, ๆ 24; Schlaepfer \& Petti, supra note 1 , at 14 .

${ }^{159}$ Bovis, supra note 1,19 ("It is in accordance with the principle of party autonomy that the parties were free to choose one body as their appointing authority and another body as their rules provider.").

${ }^{160}$ Id. ๆ 21-22; Lalive, supra note 1, at 665; BLACKABY ET AL., supra note 4, 1.144 n.154; Schlaepfer \& Petti, supra note 1, at 14.

${ }^{161}$ Supra Section IV.B.1.

${ }^{162}$ Insigma v. Alstom, supra note 2, ๆ 33; FOUCHARD GAILlARD GOLDMAN, supra note 4, ๆ 359; DAVID JOSEPH, JURISDICTION AND ARBITRATION AGREEMENTS AND THEIR ENFORCEMENT 4.27 (2005); MCILWRATH \& SAVAGE, supra note 1, ๆ 1-063.
} 
institutional in nature, at least according to the traditional definitions ${ }^{163}$ outlined earlier.

However, there remain cases in which neither the arbitration agreement's reasonable construction nor a legal presumption will result in the applicability of the selected institution's arbitration rules, thereby leaving the arbitral institution as the sole institutional aspect agreed upon. This is necessarily so where no such institutional rules exist: While a good number of arbitral institutions (in particular the well-known international institutions) have their own arbitration rules, a great deal more do not. ${ }^{164}$ Another constellation are party agreements that designate arbitral institutions as appointing authorities or as case administrators under the UNCITRAL Arbitration Rules. ${ }^{165}$ In such cases, the arbitration is not institutional in spite of the parties' (isolated) choice of an institution, but rather ad hoc. ${ }^{166}$

3. Lessons Learned for the Distinction Between Arbitration Categories - Legal practice with regard to arbitration agreements choosing only an arbitral institution (without the institution's in-house arbitration rules) or only institutional arbitration rules (without the issuing institution's administration) shows a strong tendency to construe such clauses as also selecting the missing component, either by relying on express legal rules in this respect or on general rules of interpretation. Whenever such a constructive approach succeeds, the arbitration concerned qualifies as institutional. In the remaining cases, the involvement of only an arbitral institution or only institutional arbitration rules usually means that the arbitration is regarded as ad hoc. Borderline cases of this type thereby demonstrate that both components are required for an arbitration to be "institutional": In addition to the use of institutional rules, at least some involvement of the arbitral institution beyond having drafted the respective rules is needed.

\section{Modification of Institutional Rules by the Parties}

The third type of borderline cases concerns the modification of institutional arbitration rules by the parties to an arbitration, or-maybe more to the point - the limits of such modifications. It is generally recognized that party autonomy also reigns supreme in institutional arbitration, ${ }^{167}$ allowing the parties to modify institutional arbitration rules to meet the needs of their particular transaction. Some institutional rules

\footnotetext{
${ }^{163}$ Supra Section II.B.

${ }^{164}$ GERBAY, supra note 32, at 13.

${ }^{165}$ Supra Section IV.A.2., 3.

${ }^{166}$ Zhou, supra note 59, at 146.

${ }^{167}$ See supra note 76.
} 
contain express provisions to this end. ${ }^{168}$ At the same time, there is widespread agreement that party autonomy in institutional arbitration is not unlimited, ${ }^{169}$ but in fact more limited than in ad hoc arbitration: While ad hoc and institutional arbitrations alike have to respect the mandatory provisions of the lex arbitri, ${ }^{170}$ institutional arbitration rules may contain further provisions from which the parties cannot derogate. ${ }^{171}$ Article 7(6) of the 2013 Vienna Rules ${ }^{172}$ explicitly provides that the International Arbitral Centre of the Austrian Federal Economic Chamber (VIAC) can refuse to administer proceedings if the arbitration agreement "deviates fundamentally from and is incompatible with" the Vienna Rules. However, already under the Vienna Rules' previous version that still indiscriminately referred to any agreement "deviating from" the institutional rules, commentators agreed that a refusal to administrate was only justified in very narrow circumstances ${ }^{173}$ where the parties attempt to modify provisions from which they are not allowed to derogate. ${ }^{174}$

1. Non-Derogatable ("Mandatory") Provisions in Institutional Arbitration Rules - Provisions in institutional rules from which the parties may not derogate are often referred to as "mandatory" arbitration rules, ${ }^{175}$ although this term is arguably misleading: ${ }^{176}$ Given that institutional

\footnotetext{
168 International Centre for Dispute Resolution (ICDR) International Dispute Resolution Procedures, art. 1(1) (2014), https://www.adr.org/sites/default/files/ICDR\%20Rules\%20English \%20Version\%20June\%202014.pdf; American Arbitration Association (AAA) Commercial Arbitration Rules and Mediation Procedures, art. R-1(a) (2013), https://www.adr.org/sites/default/ files/Commercial\%20R ules.pdf.

${ }^{169}$ Böckstiegel, supra note 5, at 2; Carlevaris, supra note 76, at 115; Elliott Geisinger, The Expedited Procedure Under the Swiss Rules of International Arbitration, in THE SwISS RULES OF INTERNATIONAL ARBITRATION 67, 77 (Gabrielle Kaufmann-Kohler \& Blaise Stucki eds., 2004); Patocchi \& Niedermaier, supra note 79, ๆ 17; BLACKABY ET AL., supra note 4, 9.16; Schäfer, supra note 14, 1340; SCHERER ET AL., supra note 76, at 36; Robert H. Smit, Mandatory ICC Arbitration Rules, in LIBER AMICORUM IN HONOUR OF ROBERT BRINER 845, 847 (2005); VERBIST ET AL., supra note 15, at 16.

${ }^{170}$ Anthony C. Nicholls \& Christopher Bloch, ICC Hybrid Arbitrations Here to Stay: Singapore Courts' Treatment of the ICC Rules Revisions in Article 1(2) and 6(2), 31 J. INT'L ARB. 393, 404 (2014); BLACKABY ET AL., supra note 4, ๆ 1.140.

${ }^{171}$ Supra note 169.

${ }^{172}$ Vienna International Arbitration Centre (VIAC) Rules of Arbitration and Mediation, art. 7(6) (2013).

${ }^{173}$ Vienna International Arbitral Centre (VIAC) of the Austrian Federal Economic Chamber Rules of Arbitration and Conciliation, art. 9(6) (2006); FrANZ T. SCHWARZ \& CHRISTIAN W. KONRAD, THE VIENNA RulEs: A COMMENTARY ON INTERNATIONAL ARBITRATION IN AUSTRIA ๆף 9-092, 9093 (2009)

${ }^{174}$ Christoph Liebscher, Vienna Rules, in InSTITUTIONAL ARBITRATION, supra note 9, at 316, 109-15.

${ }^{175}$ See Böckstiegel, supra note 5, at 2; Sébastien Besson, Introduction to the Swiss Rules, in SwISS RULES OF INTERNATIONAL ARBITRATION: COMMENTARY - 30 (Tobias Zuberbühler et al. ed., 2005); Geisinger, supra note 169, at 78; SCHERER ET AL., supra note 76, at 36; Smit, supra note 169 , at 845; THOMAS H. Webster \& MiCHAEL W. BÜHLER, HANDBOOK OF ICC ARBITRATION: COMMENTARY, PRECEDENTS, MATERIALS $\uparrow$ 1-30 (2014).

${ }^{176}$ Carlevaris, supra note 76, at 114; Nicholls \& Bloch, supra note 170, at 404.
} 
arbitration rules apply by the parties` choice and not by law, any provisions in arbitration rules chosen are no more mandatory than contractual clauses purporting to derogate from them. In other words, the conflict is not between the will of the parties and the law, but between two different expressions of the parties' will. ${ }^{177}$ As a result, an arbitration agreement attempting to derogate from a non-derogatable (or non-amendable ${ }^{178}$ ) institutional arbitration rule is not (or not necessarily) invalid. ${ }^{179}$ However, it gives the arbitration institution the right to refuse the arbitration's administration if the parties do not accept the unfettered application of the institutional rules' non-derogatable provisions. ${ }^{180}$

For the purposes of the present article, cases involving a modification of institutional arbitration rules are of interest as a "borderline case" because they attempt to combine a crucial characteristic of institutional arbitration - the proceedings' administration by an institutional body - with a distinguishing feature of ad hoc arbitration - the parties' freedom to tailor their arbitration's procedure to their specific needs. When regarded in this manner, non-derogatable (or "mandatory") provisions of institutional arbitration rules could be expected to reflect the core characteristics of institutional arbitration, the very features that parties cannot dispense with without losing the institutional character of their arbitration.

Do the limits of party autonomy unique to institutional arbitration therefore show us what makes institutional arbitration "institutional"?

2. Examples of Non-Derogatable Institutional Rules - In order to answer this question, we must first identify the provisions in institutional arbitration rules that parties may not derogate from. Insofar, we are not concerned with those non-derogatable provisions in institutional rules that merely mirror mandatory rules of the lex arbitri (or, more rarely, of other legal orders), as notably provisions imposing a duty on arbitrators to remain impartial and independent of the parties or guaranteeing the parties' equal treatment and their right to be heard. ${ }^{181}$ Given that such standards already flow from the mandatory standards of most leges arbitri, the content of such institutional provisions do not reflect what is unique to institutional arbitration. Beyond this, arbitration experts generally admit that the nonderogatable, institution-specific core of institutional rules is far from

\footnotetext{
${ }^{177}$ Carlevaris, supra note 76 , at 114 .

${ }^{178}$ This term is used by Nicholls \& Bloch, supra note 170, at 404-05.

179 Besson, supra note 175, I37; Nicholls \& Bloch, supra note 170, at 404-05; see also CARBONNEAU, supra note 4, at 617.

${ }^{180}$ Carlevaris, supra note 76, at 115; LAURENCE W. CRAIG ET AL., INTERNATIONAL CHAMBER OF COMMERCE ARBITRATION 295 (2000); Geisinger, supra note 169, at 77; Andreas Reiner \& Christian Aschauer, ICC Rules, in Institutional ARBITRATION, supra note 9, 38, ף 27; SCHWARTZ \& DERAINS, supra note 126, at 7-8; Smit, supra note 169, at 847; VERBIST ET AL., supra note 15, at 16; WEBSTER \& BÜHLER, supra note 175, ๆ 1-29.

${ }^{181}$ See in more detail the overview in BORN, supra note 1, at 2163-84.
} 
clear. ${ }^{182}$ To make matters worse, this core differs from institution to institution.

In case of the ICC Rules, "mandatory" features identified by commentators are the fixing of arbitrators' fees and expenses by the ICC Court $^{183}$ (Article 2(4) of Appendix III to the 2017 ICC Rules expressly saying so); the appointment and confirmation of arbitrators in ICC arbitrations $^{184}$ (Articles 12(8) and 13 of the 2012 ICC Rules); the ICC's court role in screening requests for arbitration and jurisdictional objections as well as deciding on its own competence to administer a case ${ }^{185}$ (Articles $6(3)$ and (4) of the 2017 ICC Rules); the uneven number of arbitrators on the tribunal (Articles 12(1) of the 2012 ICC Rules), unless the parties have agreed on a procedure to resolve a possible deadlock; ${ }^{186}$ the majority requirement for awards made by a three-member tribunal ${ }^{187}$ (Article 32(1) of the 2017 ICC Rules); and the scrutiny of draft awards by the ICC Court $^{188}$ (Article 34 of the 2017 ICC Rules). ${ }^{189}$ The Terms of Reference procedure (Article 23 of the 2017 ICC Rules) has also often been named, ${ }^{190}$ although commentators have more recently started to doubt its nonderogatable nature. ${ }^{191}$ The latter position has received support by the 2017 ICC Rules now dispensing with the Terms of Reference whenever an arbitration is conducted under the new Expedited Procedure Rules (Article 3(1) of Appendix VI to the 2017 ICC Rules).

\footnotetext{
${ }^{182}$ With regard to the ICC Rules see Richard H. Kreindler, Impending Revision of the ICC Arbitration Rules: Opportunities and Hazards for Experienced and Inexperienced Users Alike, 13(2) J. INT'L ARB. 45, 56 (1996); SChWARTZ \& DERAINS, supra note 126, at 8; with regard to the LCIA Rules see SCHERER ET AL., supra note 76, at 37; with regard to the Swiss Rules see Besson, supra note 175 , at 930.

${ }^{183}$ Carlevaris, supra note 76, at 116; FRY ET AL., supra note 156, - 3-17; VERBIST ET AL., supra note 15, at 16; WEBSTER \& BÜHLER, supra note 175, $91-30$; but see Smit, supra note 169, at 86768 .

${ }^{184}$ Carlevaris, supra note 76, at 123-24; Reiner \& Aschauer, supra note 180, at 927 ; Smit, supra note 169 , at 858,860 .

${ }^{185}$ Carlevaris, supra note 76, at 120; Smit, supra note 169, at 853-54.

${ }^{186}$ Reiner \& Aschauer, supra note $180, \uparrow 27$.

${ }^{187}$ Smit, supra note 169 , at 863 .

${ }^{188}$ Carlevaris, supra note 76, at 119; CRAIG ET AL., supra note 180, at 295; CROFT ET AL., supra note 79, 1.1; FRY ET AL., supra note 156, \ 3-17; MARTIN F. GUSY ET AL., A GUIDE TO THE ICDR INTERNATIONAL ARBITRATION RULES \ 1.92 (2011); Reiner \& Aschauer, supra note 180, at $\ 27$; Schäfer, supra note 14, \314; Smit, supra note 169, at 865; VERBIST ET AL., supra note 15, at 16; WEBSTER \& BÜHLER, supra note 175, ๆ 1-30.

${ }^{189}$ Further, mandatory provisions are Article 1(2) of the 2017 ICC Rules dealing with "mix and match" arbitrations (to be discussed in detail infra at IV.D.), and Article 6(2) of the 2017 ICC Rules (already addressed supra at IV.B.1.).

${ }^{190}$ FRY ET AL., supra note 156, at 9 -17; GUSY ET AL., supra note 188, at 91.92 ; SCHWARTZ \& DERAINS, supra note 126, at 5-6; VERBIST ET AL., supra note 15, at 16; WEBSTER \& BÜHLER, supra note 175, , 1-30.

${ }^{191}$ Smit, supra note 169 , at 862-63; Carlevaris, supra note 76 , at 120-21.
} 
Under the LCIA Rules, the LCIA Court's power to appoint the arbitral tribunal (Article 5.7 of the 2014 LCIA Rules), ${ }^{192}$ its power to decide on the arbitration costs (Article 28.1 of the 2014 LCIA Rules) as well as the LCIA's Schedule of Costs in general have been identified as nonderogatable. $^{193}$

In case of the Swiss Rules of International Arbitration, non-derogatable provisions concern the confirmation of arbitrators by the Swiss Chambers (Article 5(1) of the 2004 Swiss Rules), the challenge and revocation of the appointment of arbitrators by the Special Committee (Articles 11 and 12 of the 2004 Swiss Rules), and provisions protecting the interest of the Swiss Chambers, like the rules on the scrutiny of awards on the issue of costs (Article 40(4) of the 2004 Swiss Rules and Appendix B about the costs of the proceedings, at least to the extent that the registration fee and the Chambers' administrative costs are concerned) or the exclusion of the Chambers' liability (Article 44 of the 2004 Swiss Rules). ${ }^{194}$ The matter is viewed as less clear for the arbitral tribunal's duty to prepare a provisional timetable (Article 15(3) of the 2004 Swiss Rules) ${ }^{195}$ and for the rules about the expedited procedure (Article 42(2) of the 2004 Swiss Rules). ${ }^{196}$

Under the DIS Arbitration Rules, the provisions on the confirmation of arbitrators by the institution ( $§ 17$ of the 1998 DIS Arbitration Rules), ${ }^{197}$ on the termination of arbitral proceedings by the tribunal $(\S 32$ and $\S 39$ of the 1998 DIS Arbitration Rules), ${ }^{198}$ on administrative fees and on the provisional advance on costs $(\S 7, \S \S 11(1),(2), \S 25$ and $\S 40$ of the 1998 DIS Arbitration Rules) ${ }^{199}$ are regarded as non-derogatable.

\footnotetext{
${ }^{192}$ SCHERER ET AL., supra note 76, at 36-37; see also WADE, CLIFFORD \& CLANCY, supra note 76, II 5-044.

${ }^{193}$ SCHERER ET AL., supra note 76, at 36-37; see generally Adrian Winstanley, Party Autonomy and Institutional Rules, in 8TH BIENNIAL IFCAI CONFERENCE (2005).

${ }^{194}$ Besson, supra note 175 , at 32 . For a more flexible view, see Geisinger, supra note 169 , at 78 .

${ }^{195}$ See Besson, supra note 175, at 32 ("possibly"); Tina Wüstemann \& Cesare Jermini, Article 15, in SWiss RUles OF INTERNATIONAL ARBITRATION: COMMENTARY, supra note 175 q 6 ("probably"); Daniel B. Wehrli et al., Management of the Proceedings and Quality Control Under the Swiss Rules, in THE Swiss RULES OF INTERNATIONAL ARBITRATION, supra note 169, 87, 97 ("the only mandatory organizational tool under the Swiss Rules").

${ }^{196}$ See Geisinger, supra note 169 , at 78-79.

197 Thomas Klich, $\$ 17$ DIS-SchO, in ICC-SCHO/DIS-SCHO: PRAXISKOMMENTAR ZU DEN SCHIEDSGERICHTSORDNUNGEN, supra note 1, ๆ 20-21.

198 Friederike Stumpe \& Heiko A. Haller, \&32 DIS-SchO, in ICC-SCHO/DIS-SCHO: PRAXISKOMMENTAR ZU DEN SCHIEDSGERICHTSORDNUNGEN, supra note 1, ब 12; Meike von Levetzow, $\$ 39$ DIS-SchO, in ICC-SCHO/DIS-SChO: PRAXISKOMMENTAR ZU DEN SCHIEDSGERICHTSORDNUNGEN, supra note 1, ๆ 78.

${ }^{199}$ Alexander Schilling, $\S 7 \mathrm{DIS}-\mathrm{SchO}$, in ICC-SCHO/DIS-SCHO: PRAXISKOMMENTAR ZU DEN SCHIEDSGERICHTSORDNUNGEN, supra note 1, \ 15; Simon Manner, $\S 11$ DIS-SchO, in ICCSCHO/DIS-SCHO: PRAXISKOMMENTAR ZU DEN SCHIEDSGERICHTSORDNUNGEN, supra note 1, ๆ 12; Heiko A. Haller, $\S 25$ DIS-SchO, in ICC-SCHO/DIS-SCHO: PRAXISKOMMENTAR ZU DEN SCHIEDSGERICHTSORDNUNGEN, supra note 1, \ 17.
} 
In contrast, the generously-drafted Article 1(1) of the 2014 ICDR (AAA) International Arbitration Rules ("subject to whatever modifications the parties may adopt in writing") seems to grant absolute precedence to party autonomy. ${ }^{200}$

3. Non-Derogatable Institutional Rules as "Core" of Institutional Arbitration? - The overview of the non-derogatable provisions contained in the institutional rules of a few selected arbitral institutions has most of all made apparent that these "mandatory" institutional rules are far from uniform, rendering it difficult to regard them as an indication of the core of institutional arbitration in a general sense. Instead of reflecting the characteristic features of institutional arbitration that are not present in ad hoc arbitration, they rather reflect cornerstones of a particular institution's arbitration. ${ }^{201}$ The latter becomes notably apparent when taking into account the many institutional arbitration rules that have been closely modelled on the UNCITRAL Arbitration Rules ${ }^{202}$ (including the changes introduced by their 2010 revision $^{203}$ ), with some institutional rules being virtual copies of the UNCITRAL Rules: As any "mandatory" core of such institutional rules would necessarily resemble the non-derogatable provisions of the UNCITRAL Arbitration Rules, this core can by definition not be characteristic for institutional arbitration only, because it is similarly present in UNCITRAL (and therefore, as addressed earlier, ${ }^{204}$ ad hoc) arbitrations.

In other words, it is not the content of non-derogatable institutional arbitration rules that can inform us about the nature of institutional arbitration. As will be demonstrated below, the "mandatory" core of institutional rules nevertheless provides us with important input about the borders of institutional arbitration, albeit for a different reason.

4. Case Law on Attempted Party-Derogations from Non-Derogatable Institutional Rules — The effects of party attempts to derogate from "mandatory" institutional arbitration rules became apparent in Samsung Electronics $v$. Qimonda, a case decided by the Tribunal de Grande Instance

\footnotetext{
${ }^{200}$ See GuSY, Hosking \& SCHWARZ, supra note 188, ๆๆ 1.91-92; similarly on Article 1(1) of the 2009 ICDR Rules Martin F. Gusy et al., ICDR International Arbitration Rules, in PRACTITIONER's HANDBOOK ON INTERNATIONAL COMMERCIAL ARBITRATION 17.53 (Frank-Bernd Weigand ed., 2009). On the comparable wording of Article 2(1) of the 1988 ICC Rules see Kreindler, supra note 182 , at 56 .

${ }^{201}$ See Geisinger, supra note 169, at 77 (writing in general); VERBIST ET AL., supra note 15, at 16; WEBSTER \& BÜHLER, supra note 175, ๆ 1-30 (both on the ICC Rules); Besson, supra note 175, I 31 (on the Swiss Rules).

${ }^{202}$ See BORN, supra note 1, at 173-74; Perales Viscasillas, supra note 8, at 53-54; BLACKABY ET AL., supra note 4, 11.157.

${ }^{203}$ See WIDDASCHECK, supra note 9, at 29.

${ }^{204}$ Supra Section IV.A.
} 
de Paris in $2010 .^{205}$ It arose from a license contract in which the parties had agreed to have any dispute decided by ICC arbitration, but without the arbitrators' appointment having to be confirmed by the ICC Court or the arbitral award undergoing scrutiny by the ICC Court. Their arbitration agreement accordingly derogated from not only one, but two features of the ICC Rules that are commonly viewed as non-derogatable, ${ }^{206}$ attempting to exclude the arguably most invasive powers of the ICC. ${ }^{207}$ Because of those derogations, the ICC Secretariat refused to administer the arbitration ${ }^{208}$ and, when the defendant did not agree to remove those derogations, declared the arbitration proceedings terminated. ${ }^{209}$ In light of this development, the parties agreed to conduct an $a d$ hoc arbitration, with the two already partyappointed arbitrators and with the ICC as appointing authority, should one be needed in order to appoint the presiding arbitrator. ${ }^{210}$

The decision in Samsung Electronics provides two important insights into the factors determining the nature of an arbitration as institutional or ad hoc. The first insight is the confirmation of an arbitral institution's power (here: the power of the ICC) to decide whether an arbitration can go forward where the parties have attempted to derogate from provisions in the institution's rules that the institution considers to be non-derogatable. Although the parties to the arbitration have agreed upon the derogations from the institutional rules as much as upon the institutional rules' application to their arbitration, the institution possesses the right to determine the institutional nature of the arbitration: If it decides (one may add: in accordance with its institutional rules) that an arbitration cannot continue, the proceedings are no longer institutional. In institutional arbitration, the arbitral institution therefore exercises what may be called a "gatekeeper function".

The second insight from the Samsung Electronics case concerns an arbitration's nature once the "gatekeeping" institution has exercised its gatekeeper function to a negative end, deciding that the arbitration cannot continue under its administration as an institutional arbitration. In Samsung, the parties had seemingly agreed under the court's guidance (with the court acting as juge d'appui in accordance with the French law of arbitration) to continue the proceedings that commenced as an institutional arbitration as an ad hoc arbitration. The institutional arbitration thereby "mutated" into

\footnotetext{
${ }^{205}$ Tribunal de Grande Instance [TGI] [ordinary court of original jurisdiction] Paris, Jan. 22, 2010, 10/50604, 571 (Fr.) [hereinafter Samsung v. Qimonda AG].

${ }^{206}$ Supra Section IV.C.2.

${ }^{207}$ Racine, supra note 24, at 578.

${ }^{208}$ Samsung v. Qimonda AG, supra note 205, at 574-75.

${ }^{209} \mathrm{Id}$. at 575 .

${ }^{210} I d$.
} 
an ad hoc arbitration. ${ }^{211}$ But even if no such subsequent agreement would have been reached between the parties, the result would arguably have been the same: Irrespective of the applicable lex arbitri (i.e., also where the applicable arbitration law is that of a jurisdiction other than France), an interpretation of the arbitration agreement would lead to the conclusion that the parties intended to continue their proceedings even if the institution named refuses its administration, although it would then be an ad hoc arbitration $^{212}$ (and neither an institutional nor a third category of arbitration).

5. Institution's Gatekeeper Function as Decisive Characteristic of Institutional Arbitration - The case law on attempted derogations from non-derogatable institutional rules provides a crucial guidepost in defining institutional arbitration: It is submitted that it is an arbitral institution's power, given to the institution through the parties' agreement on its institutional arbitration rules, to unilaterally preserve the core characteristics of its arbitration procedure (as, in Samsung Electronics, the ICC's confirmation of arbitrator appointments and its scrutiny of arbitral awards) what makes an institutional arbitration "institutional". The authority of an institution to protect the core characteristics of its institutional arbitration, its final decision about desired derogations from its rules, constitutes a decisive third-party involvement well-suited to distinguish institutional from other arbitrations. The focus on this "gatekeeper function" avoids the uncertainties inherent in both a reliance on the characteristic "core" of institutional arbitration rules ${ }^{213}$ and in attempts to define arbitral institutions, because it is unclear what factors make an institution an arbitral institution. ${ }^{214}$ Instead, the present approach looks to the institution's decision-making power in relation to the parties to an arbitration.

A gatekeeper function as described here is particular to certain arbitral institutions. On the one hand, it distinguishes them from mere appointing authorities, because and as far as the parties cannot overrule the arbitral institution's decision and nevertheless preserve the institutional nature of their arbitration. An institution's decision-making power of this kind exceeds an appointing authority's power to appoint arbitrators under domestic laws because the latter appointments are not binding on both parties, who in spite of it could agree on different arbitrators. (To be clear,

\footnotetext{
${ }^{211}$ Racine, supra note 24, at 576; see generally CARBONNEAU, supra note 4, at 11 ("Too great an emphasis on the use of party discretion, however, can transform an institutional arbitration into an ad hoc proceeding.").

${ }^{212}$ Detlev Kühner, Anmerkung, in ZEITSCHRIFT FÜR SCHIEDSVERFAHREN 239, 240 (2013); Nicholls $\&$ Bloch, supra note 170 , at 405.

${ }^{213}$ Supra Section IV.C.3.

${ }^{214}$ On the difficulties to define the similar term "permanent arbitral institution", see supra Section IV.A.3.(c).
} 
the power to make decisions that are binding on only one party is insufficient in this regard, as such a power is typical for appointing authorities in $a d$ hoc and institutional arbitrations alike. ${ }^{215}$ ) On the other hand, a gatekeeper function is not necessarily exercised by every arbitral institution (however defined), because the required decision-making power must be delegated to the institution through the institutional rules. The presence of a gatekeeper function therefore depends on the role given to the respective institution by its rules, which means that not every arbitral institution conducts "institutional" arbitrations in the sense proposed here.

The present approach does not presuppose any specific content of the rules that an arbitral institution is entitled to preserve. It thereby accomodates the procedural differences between the various arbitral institutions, including the differences in the non-derogatable part of their respective arbitration rules that was outlined earlier. ${ }^{216}$

Where it is present, the gatekeeper function implements an additional limit to the parties' autonomy not existent in ad hoc arbitration. In case an arbitral institution vested with the necessary decision-making power denies its consent to have an arbitration move forward under its rules, such an arbitration no longer qualifies as "institutional", even if it nevertheless should be continued by the parties.

6. Lessons Learned for the Distinction Between Arbitration Categories - If an arbitration institution named in an arbitration agreement refuses to administer the arbitration because the parties have derogated from provisions in the institutional arbitration rules that the institution considers non-derogatable, the arbitration cannot proceed as an institutional arbitration. ${ }^{217}$ If the parties and the arbitral tribunal proceed nonetheless in such a situation, the arbitration continues as an $a d$ hoc arbitration. ${ }^{218}$ This indicates that an arbitral institution's power to unilaterally preserve the core characteristics of its institutional arbitration procedure is what makes an institutional arbitration "institutional". ${ }^{219}$ Where this gatekeeper function has resulted in the institution not allowing an arbitration to proceed under its auspices, this decision cannot prevent the parties from nevertheless using the institutional arbitration rules-however, such a proceeding would then be an ad hoc arbitration. ${ }^{220}$

In contrast, the content of the non-derogatable provisions of institutional arbitration rules does not seem to reflect a universal core of institutional arbitrations, but rather demonstrates the significant variety of

\footnotetext{
${ }^{215}$ See UNCITRAL Model Law, supra note 49, arts. 11(3)-(5) and further infra Section V.B.2.(a).

${ }^{216}$ See supra Section IV.B.2.

${ }^{217}$ Supra Section IV.C.4. and Nicholls \& Bloch, supra note 170, at 405.

${ }^{218}$ Kühner, supra note 212, at 240; Nicholls \& Bloch, supra note 170 , at 405.

${ }^{219}$ Supra Section IV.C.5.

${ }^{220}$ See also SCHWARZ \& KONRAD, supra note 173, ๆ 9-102.
} 
arbitral proceedings and of the procedural involvement of different institutions. $^{221}$

\section{D. "Mix and Match" (or "Hybrid") Arbitrations}

The fourth and last group of borderline cases are so-called "mix and match" arbitrations, often also referred to as "hybrid" 222 arbitrations.

1. Characteristics of "Mix and Match" Arbitrations - In such cases, that-luckily - are rare, the parties agree to conduct their arbitration under the rules of one arbitral institution, but to have it administered by another arbitral institution. In doing so, they therefore "mix and match" institutional rules and administering institution. In a manner of speaking, such arbitration agreements constitute a sub-type of the borderline cases just discussed $^{223}$ that involve the modification of institutional arbitration rules by the parties. They are nevertheless particular because they take the modifications to the extreme, by exchanging the entire arbitral institution that has designed the applicable rules for a different administering institution.

The first case to put "mix and match" arbitrations into the spotlight was the famous (or rather infamous) case Insigma Technology Co. Ltd. v. Alstom Technology Ltd., ${ }^{224}$ decided by the Singapore High Court in 2008. It involved an arbitration clause that called for "arbitration before the Singapore International Arbitration Centre in accordance with the Rules of Arbitration of the International Chamber of Commerce". 225 Similar cases that have resulted in published court decisions concerned agreements about arbitrations to be conducted pursuant to the ICC Rules, but to be administered by the AAA; ${ }^{226}$ another one to be conducted pursuant to the ICC Rules, but to be administered by the SCC; ${ }^{227}$ and-again-disputes to "be referred to Singapore International Arbitration Center (hereinafter "SIAC") for arbitration in accordance with the Rules of Conciliation and Arbitration of the International Chamber of Commerce." ${ }^{228}$ Practitioners

${ }^{221}$ Supra Section IV.C.3.

${ }^{222}$ HKL Group Co. Ltd. v. Rizq International Holdings Pte. Ltd., [2013] SGHCR 5, ๆ 28 (Sing.) [hereinafter HKL v. Rizq]; Kirby, supra note 21, at 325; Nicholls \& Bloch, supra note 170, at 393.

${ }^{223}$ Supra Sectiont IV.C.

${ }^{224}$ See generally Insigma Technology Co. Ltd. v. Alstom Technology Ltd., [2008] SGHC 134 (Sing.) [hereinafter Insigma v. Alstom 2008].

${ }^{225}$ Id. 93

${ }^{226}$ Exxon Neftegas Ltd. v. WorleyParsons Ltd., Supreme Court of the State of New York, County of New York, Order of 16 July 2014, Case no. 654405/2013, per Ramos J [hereinafter Exxon v. Worley Parsons].

${ }^{227}$ Russian Federation v. I.M. Badprim S.R.L., Svea Court of Appeal, Judgment of 23 January 2015, Case no. 2454-14.

${ }^{228}$ Top Gains Minerals Macao Commercial Offshore Ltd. v. TL Resources Pte. Ltd., [2015] C.F.I. 2101, ๆ 43-45 (H.K.); see also HKL v. Rizq, supra note 222, ๆ 1 (where the arbitration clause used referred to a (non-existant) "Arbitration Committee at Singapore" and to the ICC Rules.). 
assume more cases to have occurred ${ }^{229}$ that have remained confidential, because none of the parties involved has resorted to court proceedings.

2. Potential Insight into the Factors that Make Arbitrations Institutional - For the discussion about arbitration categories, "mix and match" arbitrations are of interest because they aim at a separation of the two components traditionally considered characteristic for institutional arbitrations, ${ }^{230}$ namely an institution's arbitration rules and an institution's administration of the proceedings. While, as a rule, arbitral institutions administer proceedings in accordance with their own ("in-house") rules, 'mix and match' arbitrations constitute an exception. Can their unusual disconnection of rules and administration provide us with additional insight into the nature of institutional arbitration?

3. Case Law on "Mix and Match" Arbitrations - As "mix and match" arbitrations involve not only one, but two arbitral institutions (albeit in a particular way), one could be tempted to think that such arbitrations must $a$ fortiori qualify as institutional arbitrations. ${ }^{231}$ Other commentators regard hybrid arbitrations as neither institutional nor ad hoc arbitrations, but rather a third category. ${ }^{232}$

(a) Insigma Technology v. Alstom Technology - In Insigma, the Singapore Court of Appeal adopted a yet different position. In affirming the High Court's views in this regard, it held as follows:

The arrangement provided for in [the Arbitration Agreement] would be unworkable if the SIAC was unable to provide similarly equipped actors to fulfil the roles that the ICC Rules gave to the institutional bodies of the ICC. However, while it might not be advisable to use the ICC Rules for most ad hoc arbitrations because of the need for an administering body, if the ad hoc arbitration nominates a substitute institution to administer the arbitration and such substitute can arrange organs to carry out similar functions to those carried out by the different parts of the ICC apparatus, there should be no practical problem, as well as no objection in principle, to providing for such a hybrid ad hoc arbitration administered by one institution but governed by the rules (as adapted where necessary) of another. This freedom is inherent in the flexible nature of arbitration, especially ad hoc arbitration. In any case, inefficiency alone cannot render a clause

\footnotetext{
${ }^{229}$ Simon GreEnBerg et AL., InTERnAtional Commercial Arbitration: An ASia-PACific PeRSPECTIVE (2011), - 4.176; Kirby, supra note 21, at 325 ("not uncommon"); Nedden \& Herzberg, supra note 95, ๆ 16.

${ }^{230}$ Supra Section II.B.

${ }^{231}$ In this sense see Perales Viscasillas, supra note 8, at 39.

${ }^{232}$ Nicholls \& Bloch, supra note 170 , at 405.
} 
invalid so long as the parties had agreed and intended for the arbitration to be conducted in this manner. ${ }^{233}$

For the purposes of the present investigation, it is striking that the Singapore Court of Appeal did not consider the 'mix and match' arbitration to be institutional in nature, but rather an ad hoc proceeding of a particular kind. ${ }^{234}$ More precisely, it spoke of an "hybrid ad hoc arbitration administered by one institution but governed by the rules (as adapted where necessary) of another". ${ }^{235}$ While authors have generally agreed that any arbitration conducted under the ICC Rules but not administered by the ICC cannot qualify as an ICC arbitration, ${ }^{236}$ the Singapore Court of Appeal went further by ruling that it constitutes no institutional arbitration at all.

Unfortunately, the Court of Appeal did not elaborate on the reasons underlying its approach. Commentators have noted that the High Court in Insigma did not use the term "ad hoc arbitration" to refer to arbitration that is not administered by an arbitral institution, as is most frequently done, ${ }^{237}$ but in order to refer to an arbitration that "is conducted pursuant to rules agreed by the parties themselves or laid down by the arbitral tribunal"238 but not, one could add, pursuant to rules laid down by an arbitral institution. ${ }^{239}$ Based on this relatively broad understanding of ad hoc arbitration, the High Court essentially treated the arbitration rules agreed by the parties as an ad hoc version of the ICC Rules. ${ }^{240}$

(b) Exxon Neftegas v. WorleyParsons - In Exxon Neftegas, ${ }^{241}$ parties had mixed and matched the ICC Rules with the proceedings' administration by the AAA. In spite of the arbitration agreement, Exxon brought a suit in a New York court. WorleyParsons filed a motion to stay and to compel arbitration in the Supreme Court of the State of New York, and at the same time commenced an arbitration before the ICC under the ICC Rules. Exxon

\footnotetext{
${ }^{233}$ Insigma v. Alstom, supra note 2, \ 35.

${ }^{234}$ Willems, supra note 59, at 405.

${ }^{235} \mathrm{Id}$.

${ }^{236}$ FRY ET AL., supra note 156, 9 3-194; Perales Viscasillas, supra note 8, at 37; Reiner \& Aschauer, supra note $180, \boldsymbol{\Upsilon} 28$.

${ }^{237}$ Kirby, supra note 21, at 324.

${ }^{238}$ Insigma v. Alstom 2008, supra note 224, $₫ 31$.

${ }^{239}$ See also id. 125 :
}

It is obvious from the clause, taking an objective view of its wording, that the parties did not bargain for an ICC institutional arbitration, but for an SIAC administered one and even that was not to be institutional in nature because they intended the SIAC to apply the rules of the ICC in administering the proceedings. By specifying a different set of procedural rules that was not the SIAC's in-house rules, the parties showed their desire for an ad hoc arbitration.

\footnotetext{
${ }^{240}$ Kirby, supra note 21, at 327.

${ }^{241}$ Exxon v. Worley Parsons, supra note 226.
} 
opposed the motion to stay the court proceedings, and in addition filed a cross-motion to stay the ICC arbitration. The Supreme Court of the State of New York's order was two-pronged:

First, it directed the parties to have "any arbitration administered by the American Arbitration under the ICC Rules [i.e., in exact compliance with the wording of their arbitration clause], with the parties to seek the court's assistance if they are unable to agree to any modifications of the ICC Rules required for AAA administration". In contrast to the Singapore High Court in Insigma, the court in Exxon Neftegas did not address whether the arbitration resulting from the mix and match clause accompanied by necessary rules modification would be institutional or ad hoc. (Under the standards of Insigma, it would arguably be ad hoc.)

Second, the court held that "[i]f the AAA is unwilling or unable for any reason to administer the arbitration under the ICC Rules, the reference to the ICC Rules in the arbitration clause in the Engineering Agreement is severed and the parties shall arbitrate pursuant to arbitration rules designated by the AAA according to its procedures." ${ }^{, 42}$ In doing so, the court made clear that it considered the parties' choice of the administering institution as more important than their choice of institutional rules. Furthermore, it stressed two factors that were to determine the nature of the arbitration proceeding to arise from the unmodified "mix and match" clause: The administering arbitral institution's right to decide whether it wants to administer an arbitration under another institution's rules, and, in case it is unwilling to do so, the administering institution's right to designate the arbitration rules to be used in the proceedings. By focusing on the arbitral institution's right to decide as the factor of last resort, the court in Exxon Neftegas essentially confirmed the importance of the institution's "gatekeeper function" identified earlier. ${ }^{243}$

4. Lessons Learned for the Distinction Between Arbitration Categories - The curious cases of 'mix and match' arbitrations provide us with additional insight into the factors relevant for the distinction between arbitration categories. While the scholarly discussion in this respect is still developing, case law ${ }^{244}$ has clarified that a combination of one arbitral institution's rules with a case administration by another arbitral institution does not a fortiori make the respective arbitration institutional, but rather ad hoc. This confirms that the mere combination of any institution's administration with any institution's rules is not enough for an arbitration to qualify as institutional, in spite of these two components appearing in most traditional "institutional arbitration" definitions. ${ }^{245}$ Insigma thereby

\footnotetext{
${ }^{242} I d$.

${ }^{243}$ Supra Section IV.C.5.

${ }^{244}$ Supra Section IV.D.3.

${ }^{245}$ Supra Section II.B.
} 
stands in conformity with the prevailing view on arbitrations in which the parties have chosen an arbitral institution without its institutional rules, that are generally categorized as ad hoc ${ }^{246}$ _ according to Insigma, this approach similarly applies to the party choice of an arbitral institution (here: the SIAC) together with arbitration rules issued by a different institution (here: the ICC Rules). In other words, it is only the combination of an arbitral institutions with the application of its own institutional rules that makes an arbitration institutional. In addition, the case law on "mix and match" arbitrations confirms the widely-agreed notion that ad hoc arbitration is the default category, ${ }^{247}$ while institutional arbitration is the exceptional category.

The maybe most interesting lesson to be learned from "mix and match" arbitrations is the importance that court decisions give to arbitral institutions' decision-making power. In Insigma, the court stressed that the arbitration agreement "was rendered certain and workable by the SIAC agreeing to administer the arbitration under the ICC Rules," ${ }^{248}$ before concluding: "In our view, the only aspect of uncertainty or inoperability with regard to the Arbitration Agreement was the contingency of the SIAC declining to administer the arbitration according to the ICC Rules . . ..,249 In focusing on the institution's decision to administer or not to administer the hybrid arbitration, the court's reasoning ran parallel to the French court's approach in Samsung Electronics. ${ }^{250}$ It thereby confirms the significance of arbitral institutions' gatekeeper function outlined earlier, ${ }^{251}$ given that only SIAC's decision to administer the arbitration under the ICC Rules enabled the arbitration to proceed, albeit in form of an ad hoc arbitration. (The change from one arbitration category to the other resulted from the combination of one institution's rules with another institution's administration, a distinguishing factor not present in case of attempted deviations from other non-derogatable institutional rules, as eg in Samsung Electronics.) A focus on the arbitral institution's gatekeeper function is also apparent in Exxon Neftegas, when the Supreme Court of the State of New York orders the parties to "arbitrate pursuant to arbitration rules designated by the AAA according to its procedures", "[i]f the AAA is unwilling or unable for any reason to administer the arbitration under the ICC Rules". ${ }^{252}$ By explicitly declaring the institution's unwillingness to administer the hybrid (ad hoc) arbitration sufficient for the proceedings to continue under the AAA's auspices pursuant to AAA-designated institutional rules (and

\footnotetext{
${ }^{246}$ Supra Section IV.B.2.

${ }^{247}$ Supra Section II.C.

${ }^{248}$ Insigma v. Alstom, supra note 2, $\uparrow \uparrow$ 5, 40 (emphasis added).

${ }^{249} I d$. $\ 40$ (emphasis added).

${ }^{250}$ Supra Section IV.C.5.

${ }^{251}$ Supra Section IV.C.4.

${ }^{252}$ Exxon Neftegas v. WorleyParsons, supra note 226.
} 
therefore arguably as an institutional arbitration), the court in Exxon Neftegas similarly looked to the arbitral institution's power to make a decision that binds both parties. Finally, and in the same spirit, the Singapore High Court in HKL Group Co. Ltd. $v$ Rizq International Holdings Pte. Ltd. considered a "mix and match" arbitration clause to be workable and not null and void if the parties were "able to secure the agreement of an arbitral institution" to conduct a hybrid arbitration as described in the clause ${ }^{253}$ - by leaving the decision to administer an arbitration under rules other than its in-house arbitration rules to the unnamed institution's discretion, the court in essence acknowledged its gatekeeper function.

\section{CONSEQUENCES FOR THE DEFINITION OF ARBITRATION CATEGORIES}

In order to identify consequences to be drawn for the definition of arbitration categories, it is helpful to first briefly summarize the lessons learned from the treatment of the four groups of borderline cases. ${ }^{254}$ Based on these results, a novel definition of 'institutional arbitration' will then be outlined. $^{255}$

\section{A. Summary of the Lessons Learned from Borderline Cases}

On one hand, the earlier discussions have demonstrated that a party agreement on an arbitral institution alone does not give an arbitration an 'institutional' character, as long as it does not encompass the application of that institution's arbitration rules. ${ }^{256}$ On the other hand, neither the use of a pre-existing set of arbitration rules (like the UNCITRAL Arbitration Rules) ${ }^{257}$ nor the use of institutional arbitration rules alone (i.e., without the use of the issuing institution's services) ${ }^{258}$ suffice to make an arbitration "institutional". As an intermediate result, it is therefore clear that both the use of institutional arbitration rules and the involvement of an arbitral institution are necessary for an arbitration to be "institutional"-a requirement reflected in some, but not all traditional textbook definitions. $^{259}$

Since the Insigma case, we furthermore know that the combination of one institution's administration with another institution's rules results in an

${ }^{253}$ HKL v. Rizq, supra note 222, at $₫ \uparrow 29,37$.

${ }^{254}$ Infra Section V.A.

${ }^{255}$ Infra Section V.B.

${ }^{256}$ Supra Section IV.B.2.

${ }^{257}$ Supra Section IV.A.1.

${ }^{258}$ Supra Section IV.B.1.

${ }^{259}$ Cf. supra Section II.B. 
ad hoc arbitration, ${ }^{260}$ meaning that an institutional arbitration presupposes the proceeding's administration by an arbitral institution under that very institution's own arbitration rules.

The last and arguably most difficult question concerns the type of institutional involvement necessary to give an arbitration an institutional character. It has become clear that an arbitral institution's role as a mere appointing authority under either the UNCITRAL Arbitration Rules or domestic arbitration law is in any case insufficient for that purpose. ${ }^{261}$ Something more is required, which at the same time means that not every involvement of an arbitral institution makes an arbitration institutional. In searching for the threshold of a sufficient institutional involvement, a focus on the degree of administrative services offered has proven unhelpful, as no workable minimum standard could be identified. ${ }^{262}$ Instead, the Samsung Electronics case demonstrated that it is an arbitral institution's power to make binding decisions on certain procedural matters, having been delegated to the institution by the parties through their agreement on the institution's arbitration rules, that makes an arbitration "institutional". 263 Such a delegated power to decide provides the arbitral institution with the authority to protect certain characteristic and therefore non-derogatable features of that institution's arbitration (referred to here as "gatekeeper function"), thereby restricting the parties' autonomy to design their dispute resolution proceedings more than it is restricted in ad hoc arbitration, where merely the lex arbitri's mandatory rules must be observed. The crucial role of an arbitral institution's power to make procedural decisions binding on the parties has been confirmed by case law on "mix and match" arbitrations, in particular in the Insigma and the Exxon Neftegas case. ${ }^{264}$

Finally, the discussion of borderline cases has confirmed that the traditionally prevailing approach of distinguishing between merely two categories of arbitration - ad hoc arbitration on one hand, and institutional arbitration on the other ${ }^{265}$ - continues to be convincing, even in the face of borderline constellations that may be difficult to qualify. In other words, it is neither necessary nor helpful for the purposes identified earlier ${ }^{266}$ to introduce further (e.g., "hybrid") categories of arbitration. Among the two arbitration categories, ad hoc arbitration functions as the default category. It comprises all arbitrations that lack a sufficient involvement of arbitral institutions or of their institutional rules, among them arbitrations with

\footnotetext{
${ }^{260}$ Supra Sections IV.D.3.a. \& IV.D.4.

${ }^{261}$ Supra Section IV.A.2.

${ }^{262}$ Supra Section IV.A.3.

${ }^{263}$ Supra Sections IV.C.4. \& IV.C.5.

${ }^{264}$ Supra Sections IV.D.3. \& IV.D.4.

${ }^{265}$ Supra Section II.A.

${ }^{266}$ Supra Section III; in particular at Section III.D.
} 
some institutional involvement, but not of an institution with the necessary "gatekeeper function".

\section{B. Novel Definition of Institutional Arbitration}

1. The Definition - In light of the lessons learned, a novel definition of "institutional arbitration" could read as follows: "An arbitration is institutional if the parties, by agreeing on an institution's arbitration rules, have delegated to this arbitral institution the power to make binding decisions on certain procedural matters." Any arbitration not or no longer fulfilling these requirements is an ad hoc arbitration.

2. Explanation of the Definition - The components of the definition proposed here require a brief explanation.

(a) Arbitral Institution's Power to Make Binding Decisions — The crucial factor in an institutional arbitration is the respective arbitral institution's power to make binding decisions, its "gatekeeper function". By focusing on the institution's decision-making power and not on the administrative services rendered by the institution, the definition reflects lessons learned from case law on party agreements excluding "mandatory" (non-derogatable) institutional rules ${ }^{267}$ and on "mix and match" arbitration agreements. ${ }^{268}$ At the same time, it avoids the difficulties arising from measuring the type and degree of administrative services offered by an institution. ${ }^{269}$ In other words, the present definition does not focus on which tasks an administering institution provides (quantitative approach), but rather on how it administers its arbitrations (qualitative approach). An institution's "gatekeeper function" that results from its power to make binding decisions enables it to prevent party derogations from the core of its institutional arbitration rules, thereby protecting the characteristic features its institutional arbitrations. Although the gatekeeper function thereby restricts party autonomy in institutional arbitration more than it is restricted in ad hoc arbitration, its serves not only the institution's selfinterest ${ }^{270}$ by protecting its "brand", 271 but also has advantages for parties, arbitrators, supervising State courts and the interested public: By somewhat standardising each institution's institutional arbitrations, its guarantees the foreseeability of a particular institutional arbitration's core characteristics, thereby creating a reliable point of reference for an institutional award's

\footnotetext{
${ }^{267}$ Supra Section IV.C.4.

${ }^{268}$ Supra Section IV.D.3.

${ }^{269}$ Supra Section IV.A.3.c.

${ }^{270}$ See the oft-quoted remark by the Singapore Court of Appeal in Insigma v. Alstom, supra note 2, ๑ा 26 ("Party autonomy should trump institutional self-interest.").

${ }^{271}$ See id. 136 ("We would agree that branding in services is just as crucial as the branding of products.").
} 
extra cachet. ${ }^{272}$ In contrast, the gatekeeper function does not primarily protect an arbitration's minimum standard of fairness, as notably the parties' right to be heard and the arbitrators' impartiality: As such minimum standards must be similarly observed in ad hoc arbitration, they are guaranteed by the mandatory rules of the lex arbitri ${ }^{273}$ and enforced by the competent State courts. Insofar, a gatekeeping institution's actions may well result in an additional extra layer of protection, but are not the primary purpose of its gatekeeper function.

A focus on an arbitral institution's decision-making power is as such not entirely new in the present context. As far back as 1967, Professor Lalive considered it decisive for institutional arbitration that the institution "ne se contente pas de mettre à la disposition des parties son règlement de procédure, ses locaux, ses services administratifs, mais qu'il se réserve luimême une compétence dans I'application dudit règlement arbitral. ${ }^{, 274} \mathrm{His}$ definition differed from the approach suggested here by not requiring the power to make binding decisions, but seemingly letting any institutional competence ("une competence") suffice. More recently, another author has also regarded the institution's decisional powers as important, ${ }^{275}$ but focused on whether exercising these powers is "outcome-determinative". ${ }^{276}$

By requiring an arbitral institution's power to make "binding" decisions, the institution's gatekeeper function as suggested here assumes a decision-making power that goes beyond the legal authority to bind merely one of the parties. An institution's power of the (insufficient) latter type is present in any institution operating as appointing authority under either institutional arbitration rules, under the UNCITRAL Arbitration Rules, under a tailor-made $a d$ hoc arbitration arrangement or under domestic arbitration laws: For example, an appointing authority's decision to appoint an arbitrator where a party has failed to appoint one in time ${ }^{277}$ is binding on the inactive party, an appointing authority's decision on the challenge of an arbitrator $^{278}$ is binding on the party that had appointed the arbitrator and has not agreed to the challenge, and an appointing authority's decision to appoint a substitute arbitrator ${ }^{279}$ is binding on a party that has failed to exercise its right to appoint or to participate in the appointment of the substitute arbitrator. However, in each of these cases both parties in theory have the right to jointly deviate from the appointing authority's decision by

\footnotetext{
${ }^{272}$ See supra Section III.B.

${ }^{273}$ See UNCITRAL Model Law, supra note 49, art. 18.

${ }^{274}$ Lalive, supra note 1 , at 665.

${ }^{275}$ GERBAY, supra note 32 , at 187-88.

${ }^{276} I d$. at 195.

${ }^{277}$ United Nations Commission on International Trade Law (UNCITRAL) Arbitration Rules, arts. 8, 9(2), (3), 10(3) (2010) [hereinafter UNCITRAL Arbitration Rules].

${ }^{278}$ Id. art. 13(4).

${ }^{279} I d$. art. 14(2).
} 
agreeing on a different arbitrator, as unlikely as this may seem in practice. An arbitral institution's decisions made as an appointing authority are accordingly not binding on both parties, but merely on the party whose inactivity gave rise to the decision in the first place. The same is arguably true for an appointing authority's decision to appoint a sole arbitrator where the parties had not agreed on the number of arbitrators, as allowed under Article 7(2) of the 2010 UNCITRAL Arbitration Rules, because the parties can reach a contrary (and prevailing) agreement after the appointing authority's decision has been made.

In contrast, the gatekeeper function developed here requires more, namely the authority to bind both parties to an arbitration even where they act in agreement. In other words, the arbitral institution's decision has to be binding for the parties in the sense that they cannot deviate from the decision, even if both parties should agree on such a deviation. When construed in this way, the institution's gatekeeper function restricts procedural party autonomy in institutional arbitrations, and thereby guarantees that certain characteristic features of the institution's arbitration procedure $^{280}$ are always preserved.

Whether and to which extent a particular arbitral institution possesses decision-making powers as envisaged here is not always easy to determine. Only occasionally institutional arbitration rules clearly address the question, as in case of Article 29.1 of the 2014 LCIA Rules: By expressly providing that " $[\mathrm{t}]$ he determinations of the LCIA Court with respect to all matters relating to the arbitration shall be conclusive and binding upon the parties and the Arbitral Tribunal, unless otherwise directed by the LCIA Court", the 2014 LCIA Rules specifically grant the institution the power to make decisions that are binding on both parties. Under other institutional rules, the issue remains a matter of interpretation, with non-derogatable ("mandatory") provisions ${ }^{281}$ being a important indicative factor in this respect.

(b) On Certain Procedural Matters - The topic of the arbitral institution's required decision-making power has deliberately been framed in a non-specific manner ("on certain procedural matters"). Imposing a minimum content in this regard appears to be both unnecessary and inappropriate because a particular institution's decision-making power does not protect characteristics of institutional arbitration in general, but the indispensable features of proceedings administered by the institution concerned.

By way of clarification, it should be pointed out that an institution's power to decide on its own administrative fees or on the arbitrators'

\footnotetext{
${ }^{280}$ On the topics covered by the institution's decision-making power, see infra Section V.B.2.b.

${ }^{281}$ See, e.g., supra Section IV.C.2.
} 
remuneration - often named as one of the main advantages of institutional over ad hoc arbitration ${ }^{282}$ - is insufficient for the present purpose. The reason is that these decisions do not concern the procedural relationship between the parties, but rather their relationship to the administering institution or the arbitrators. Put differently: The fixing of the arbitral institution's administrative fees as well as of the arbitrators' remuneration isn't a matter of the parties' autonomy in the first place, because the institution (respectively the arbitrators) always have to agree to the fees suggested by the parties. Decision-making powers with regard to this issue are accordingly also found in rules designed for ad hoc proceedings, as notably the UNCITRAL Arbitration Rules that authorize the appointing authority to make adjustments to the arbitral tribunal's proposal about the determination of its fees and expenses ${ }^{283}$ and/or the arbitral tribunal's subsequent determination of fees and expenses ${ }^{284}$-decisions that Articles 41(3) and (4)(c) of the 2010 UNCITRAL Arbitration Rules expressly declare to be "binding upon the arbitral tribunal", without the parties being mentioned.

The definition's reference to "procedural" matters clarifies that no institutional decision-making power is required with respect to the substance of the dispute. This task - of course - rests with the arbitral tribunal only, in ad hoc as in institutional arbitration (however defined).

(c) Delegation of the Decision-Making Power by the Parties - Under the present definition, the arbitral institution's power to render binding decisions on procedural matters has to follow from the parties' delegation. It is therefore a creature of party autonomy, as much as international arbitration in general and the choice between $a d$ hoc and institutional arbitration in particular. ${ }^{285}$ Only by granting an institution such a power, the parties can lend their arbitration an institutional character. In contrast, arbitral institutions designated as statutory appointing authorities in some jurisdictions ${ }^{286}$ draw their decision-making powers not from the parties' delegation, but from the lex arbitri. If such an arbitration law authorizes them to render procedural decisions binding on both parties, this statutory power will not make the arbitrations concerned institutional in nature.

The relevant factor should be the parties' delegation of powers, rather than their actual use by the arbitral institution in the proceedings concerned. This is necessary in order to enable the parties to foresee their arbitration's type at the moment they conclude the arbitration agreement. In addition,

\footnotetext{
${ }^{282}$ BORN, supra note 1, at 171; GERBAY, supra note 32, at 86-87; LEW ET AL., supra note 1, at 9 23; Schäfer, supra note 14, at 9326.

${ }^{283}$ UNCITRAL Arbitration Rules, supra note 277, art. 41(3).

${ }^{284}$ Id. art. $41(4)(\mathrm{c})$.

${ }^{285}$ See supra Section II.A.

${ }^{286}$ Supra Section IV.A.2.b.
} 
focusing on the exercise of an institution's decision-making power would result in the arbitration potentially changing its nature in the course of the proceedings, a result that would not sit well with "category exclusive" provisions of law attaching legal consequences to the arbitration category. $^{287}$

(d) By Agreeing on Institutional Arbitration Rules - It is a difficult question whether such a delegation of decision powers necessarily must occur through institutional arbitration rules in order to make the arbitration "institutional", ${ }^{288}$ or whether a delegation by way of other contractual agreements would also suffice. ${ }^{289}$ The definition suggested here adopts the first approach in order to reflect the Singapore courts' position in Insigma, where the delegation of powers to the SIAC by way of the parties" "mix and match" arbitration agreement was viewed as an insufficient base for an institutional arbitration, resulting in the SIAC-administered arbitration under the ICC Rules being categorized as ad hoc. ${ }^{290}$ From the perspective of party autonomy, this requirement can be questioned, given that an individual agreement of this kind is an equally valid (and, due to its specific nature, arguably even stronger) delegation of decision-making power. However, considerations of foreseeability support a limitation to delegations via institutional rules, because it reserves the institutional arbitration category to proceedings in accordance with an institution's usual, off-the-shelf procedures.

As a related requirement also resulting from the Insigma decisions, ${ }^{291}$ the decision-making power must have been delegated through institutional arbitration rules to the very institution that has issued these rules ("have delegated to this arbitral institution"), and not to a different institution.

(e) Consequence of an Arbitration not Being in Conformity with the Definition - If a given arbitration does not conform to the suggested definition as explained here, it is not an "institutional", but an ad hoc arbitration. The same is true if the arbitration was commenced as an institutional arbitration, but the parties continue the proceedings in defiance of a binding decision by the arbitral institution: In such a case, the arbitration is no longer institutional, but ad hoc. (It is a separate question not to be discussed here in detail, whether their arbitration agreement obliges the parties to continue the arbitration ad hoc-this essentially depends on the interpretation of the arbitration agreement. ${ }^{292}$ )

\footnotetext{
${ }^{287}$ See supra Section III.C.2.

${ }^{288}$ In this sense probably see Lalive, supra note 1 , at 665.

${ }^{289}$ In this sense see GERBAY, supra note 32 , at 17.

${ }^{290}$ Supra Section IV.D.3.a.

${ }^{291}$ Id.

${ }^{292}$ SCHLOSSER, supra note 14, at I 452; SCHWARZ \& KONRAD, supra note 173, at 9 9-102; Viscasillas, supra note 8 , at 36.
} 
The limited consequences of an arbitration at first sight appearing to be "institutional", but not meeting the requirements for this category confirm that the present definition is merely concerned with the delimitation of an arbitration category, but neither with the validity of arbitral agreements nor their capability of being performed. ${ }^{293}$ Put differently: In an institutional arbitration in the sense defined here, the institution is exclusively "gatekeeping" the arbitration's institutional character, not the parties' access to arbitration in general.

Finally, the present definition maintains the long-standing dichotomy of institutional and ad hoc arbitration, thereby confirming that no third or further categories of arbitration are needed. ${ }^{294}$

\section{CONCLUSION}

The distinction between institutional arbitration on the one hand and ad hoc arbitration on the other is a basic truth of arbitration theory and practice. Used primarily for descriptive purposes, the precise delimitations of these two traditional arbitration categories are not often investigated. The present article has attempted to gather some insights into the factors that make an arbitration "institutional" or "ad hoc" by looking at four groups of borderline cases: Arbitrations conducted under a preexisting set of arbitration rules, but without or with only limited involvement of an arbitral institution acting as appointing authority or providing administrative services; isolated party choices of only institutional rules or only an arbitral institution; the modification of institutional arbitration rules by the parties (and the limit of "mandatory" provisions in those rules); and "mix and match" arbitrations combining one institution's arbitration rules with the proceedings' administration by a different arbitral institution.

The discussion of these borderline cases in case law and by scholars throws some light upon the nature of the different modes of arbitration. The conclusions drawn have resulted in the development of a novel definition of "institutional" arbitration that focuses on certain arbitral institutions" "gatekeeping function". Under this definition, not every arbitration involving an arbitral institution or institutional rules qualifies as "institutional", but only those arbitrations in which the parties have delegated to an arbitral institution the power to make binding decisions on certain procedural matters. The result of comparative research of international arbitration law and practice, the definition presented here cannot necessarily be used tel quel for the construction of domestic and international provisions addressing institutional arbitration. By contributing

\footnotetext{
${ }^{293}$ See UNCITRAL Model Law, supra note 49, art. 8(1).

${ }^{294}$ Viscasillas, supra note 8 , at 52.
} 
to the ongoing discussion about arbitration categories, the present article has already fulfilled its purpose. 


\section{REFERENCES}

$\underline{\text { Books }}$

AdOLPHSEN, JENS et al. (eds.) (2013), MÜNCHENER KOMMENTAR ZUR ZPO.

BERGER, BERNHARD \& Franz KELLERHALS (2015), INTERNATIONAL AND DOMESTIC ARBITRATION IN SWITZERLAND, $3 \mathrm{~d}$ ed.

BLACKABY, Nigel et al. (2015), REDFERN AND Hunter ON INTERNATIONAL ARBITRATION, 6th ed.

Born, GARY B. (2014), INTERNATIONAL COMMERCiAl ARbitration, 2d ed.

BÜHring-UHLE, CHRistian et al. (2006), ARBITRATION AND MEDIATION IN INTERNATIONAL BUSINESS, $2 \mathrm{~d}$ ed.

Carbonneau, Thomas E. (2007), The Law and Practice of ARBITRATION, 2d ed.

Craig, Laurence W. et al. (2000), International Chamber of COMMERCE ARBITRATION.

Croft, Clyde et al. (2013), A Guide to the UNCITRAL ARBITRATION RULES.

DERAINS, YVES \& ERIC A. SCHWARTZ (2005), A GuIDE TO THE ICC RULES OF ARBITRATION, 2d ed.

Friedland, PAul (2007), ARbitration Clauses FOR INTERNATIONAL CONTRACTS, $2 \mathrm{~d}$ ed.

Fry, JASON et al. (2012), THE SECRETARIAT's GUIDE TO ICC ARBITRATION.

GAILlARD, EMMANUEL \& JOHN SAVAGE (eds.) (1999), FoucharD GAILLARD GOLDMAN ON INTERNATIONAL COMMERCIAL ARBITRATION.

GERBAY, RÉMY (2016), THE FUNCTIONS OF ARBITRAL INSTITUTIONS.

GREENBERG, SimON et al. (2011), InTERNATIONAL COMMERCIAL Arbitration: An Asia-PACIFIC Perspective.

GRIERSON, JACOB \& ANNET VAN HOOFT (2012), ARBITRATING UNDER THE 2012 ICC RULES.

GUSY, MARTIN F. et al. (2011), A GUIDE TO THE ICDR INTERNATIONAL ARBITRATION RULES.

Holtzmann, Howard M. \& Joseph E. Neuhaus (1989), A Guide to the UNCITRAL MODEL LAW ON INTERNATIONAL COMMERCIAL ARBITRATION: LEGISLATIVE HISTORY AND COMMENTARY.

JOSEPH, DAVID (2005), JURISDICTION AND ARBITRATION AGREEMENTS AND THEIR ENFORCEMENT.

KRONKE, HERBERT et al. (eds.) (2010), RECOGNITION AND ENFORCEMENT of Foreign ARbitral AWARds: A Global COMMENTARY ON THE NEW YORK CONVENTION. 
LEW, Julian D. M. et al. (2003), COMPARATIVE INTERNATIONAL COMMERCIAL ARBITRATION.

MCILWRATH, MichaEl \& JOHN SAVAgE (2010), InTERNATIONAL Arbitration and Mediation: A Practical Guide.

MERKIN, ROBERT (2004), ARBITRATION LAW, 3d ed.

PAulsson, Marike R. P. (2016), The 1958 NeW York Convention IN ACTION.

SCHERER, MAXI et al. (2015), ARBITRATING UNDER THE 2014 LCIA RULES: A USER'S GUIDE.

SCHLOSSER, PETER (1989), DAS RECHT DER INTERNATIONALEN PRIVATEN SCHIEDSGERICHTSBARKEIT, $2 \mathrm{~d}$ ed.

SCHÜTZE, Rolf A. et al. (1990), HANDBUCH DES SCHIEDSVERFAHRENS, 2d ed.

SCHWAB, KARL HEINZ \& Gerhard WALTER (2005), SCHIEDSGERICHTSBARKEIT, 7 th ed.

SchWARZ, Franz T. \& Christian W. KonRAD (2009), THE ViennA RULES: A COMMENTARY ON INTERNATIONAL ARBITRATION IN AUSTRIA.

Sun, Wei \& Melanie Willems (2015), Arbitration in China.

Sutton, David St. John et al. (2007), Russell On ARBitration, 23th ed.

Tweeddale, Andrew \& Keren Tweeddale (2005), Arbitration of COMMERCIAL DISPUTES.

VAN OMMEREN, P.J. (1961), RAPPORT AU CONGRÈS INTERNATIONAL DE L'ARBITRAGE.

VERBist, HERMAN et al. (2015), ICC ARBITRATION IN PRACTICE, 2d ed.

WADE, Shai et al. (2015), A COMMENTARY ON THE LCIA ARBitration RULES 2014.

WAINCYMER, JEFFREY (2012), PROCEDURE AND EVIDENCE IN INTERNATIONAL ARBITRATION.

WARWAS, BARBARA ALICJA (2017), THE LIABILITY OF ARBITRAL INSTITUTIONS: LEGITIMACY CHALLENGES AND FUNCTIONAL RESPONSES.

WEBSTER, THOMAS (2010), HANDBOOK OF UNCITRAL ARBITRATION.

Webster, THOMAS H. \& MichaEl W. BÜHLER (2014), HANDBOOK OF ICC ARBITRATION: COMMENTARY, PRECEDENTS, MATERIALS.

WEIGAND, FrANK-BERND (ed.) (2009), PRACTITIONER's HANDBOOK ON INTERNATIONAL COMMERCIAL ARBITRATION.

WiddAsCheck, Mirko (2016), Die UnCitral Arbitration Rules ALS SEMI-INSTITUTIONELLE SCHIEDSVERFAHRENSREGELN.
WOLF,
CHRISTIAN
(1992),
DIE
INSTITUTIONELLE

HANDELSSCHIEDSGERICHTSBARKEIT. 
ZWEIGERT, KONRAD \& HEIN KÖTZ (1998), AN INTRODUCTION TO COMPARATIVE LAW, $3 \mathrm{~d}$ ed.

$\underline{\text { Articles }}$

Aksen, Gerald (1991), Ad Hoc Versus Institutional Arbitration, 2(1) ICC BULLETIN 8.

Basedow, Jürgen (2014), Comparative Law and its Clients, 62(4) AMERICAN JOURNAL OF COMPARATIVE LAW 821.

Besson, Sébastien (2005), Introduction to the Swiss Rules, in SWISS RULES OF INTERNATIONAL ARBITRATION: COMMENTARY (Tobias Zuberbühler et al. ed.).

Böckstiegel, Karl-Heinz (2013), Party Autonomy and Case Management-Experiences and Suggestions of an Arbitrator, 11 SCHIEDSVZ 1.

Carlevaris, Andrea (2015), The Bounds of Party Autonomy in Institutional Arbitration, in INTERNATIONAL ARBITRATION UNDER REVIEW: ESSAYS IN HONOUR OF JOHN BEECHEY 103 (Andrea Carlevaris et al. eds.).

Chapman, Brian (1986), FOSFA International Arbitration, 2(4) ARBITRATION INTERNATIONAL 323.

Chen, Helena Hsi Chia (2012), A Review of the Taiwanese Court's Ruling on Ad Hoc Arbitral Awards, 20 ASIA PACIFIC LAW REVIEW 89.

Covo, Jacques (1993), Commodities, Arbitrations and Equitable Considerations, 9(1) ARBITRATION INTERNATIONAL 57.

Drymer, Stephen L. (2010), The Revised 2010 UNCITRAL Arbitration Rules: New Rules/New Roles for Designating and Appointing Authorities, 28(4) ASA BuLLETIN 869.

Fouchard, Philippe (1979), Les Travaux de la C.N.U.D.C.I.: Le Règlement d'arbitrage, JOURNAL DU DROIT INTERNATIONAL 816.

Freyer, Dana H. (1998), Practical Considerations in Drafting Dispute Resolution Provisions in International Commercial Contracts: A US Perspective, 15(4) JOURNAL OF INTERNATIONAL ARBITRATION 7.

Geisinger, Elliott (2004), The Expedited Procedure Under the Swiss Rules of International Arbitration, in THE SWISS RULES OF INTERNATIONAL ARBITRATION 67 (Gabrielle Kaufmann-Kohler \& Blaise Stucki eds.).

Grimmer, Sarah (2011), The Expanded Role of the Appointing Authority Under the UNCITRAL Arbitration Rules 2010, 28(5) JOURNAL OF INTERNATIONAL ARBITRATION 501.

Gusy, Martin F. et al. (2009), ICDR International Arbitration Rules, in PRACTITIONER'S HANDBOOK ON INTERNATIONAL COMMERCIAL ARBITRATION (Frank-Bernd Weigand ed.).

Haller, Heiko A. (2014), §24 DIS-SchO, in ICC-SCHO/DIS-SCHO: PRAXISKOMMENTAR ZU DEN SCHIEDSGERICHTSORDNUNGEN 806 (Jan Heiner Nedden \& Axel Benjamin Herzberg eds.). 
Haller, Heiko A. (2014), §25 DIS-SchO, in ICC-ScHO/DIS-SCHO: PRAXISKOMMENTAR ZU DEN SCHIEDSGERICHTSORDNUNGEN (Jan Heiner Nedden \& Axel Benjamin Herzberg eds.).

Harris, Bruce (2011), London Maritime Arbitration, reprinted in 77 ARBITRATION 116.

Higgins, Francis J. et al. (1980), Pitfalls in International Commercial Arbitration, 35 BUSINESS LAW 1035.

Kirby, Jennifer (2009), Insigma Technology Co. Ltd. v. Alstom Technology Ltd.: SIAC Can Administer Cases Under the ICC Rules?!?, 25(3) ARBITRATION INTERNATIONAL 319.

Klich, Thomas (2014), $\S 17$ DIS-SchO, in ICC-SCHO/DIS-SCHO: PRAXISKOMMENTAR ZU DEN SCHIEDSGERICHTSORDNUNGEN (Jan Heiner Nedden \& Axel Benjamin Herzberg eds.).

Konrad, Sabine \& Robert Hunter (2013), LCIA Rules, in INSTITUTIONAL ARBITRATION 413 (Rolf A. Schütze ed.).

Korte, Mike Oliver (2004), Die Hamburger Freundschaftiche Arbitrage Ein Überblick Anlässlich des 100-jährigen Jubiläums des $\$ 20$ Platzusancen für den Hamburgischen Warenhandel, in ZEITSCHRIFT FÜR SCHIEDSVERFAHREN 240.

Kreindler, Richard H. (1996), Impending Revision of the ICC Arbitration Rules: Opportunities and Hazards for Experienced and Inexperienced Users Alike, 13(2) JOURNAL OF INTERNATIONAL ARBITRATION 45.

Kühner, Detlev (2013), Anmerkung, in ZEITSCHRIFT FÜR SCHIEDSVERFAHREN 239.

Kuo, Houchih (2012), Refusal of Taiwanese Court to Recognize Ad Hoc Arbitration: Implications and the Future of Ad Hoc Arbitration in Taiwan, ASIAN DISPUTE REVIEW 59.

Lalive, P. A. (1967), Problèmes Relatifs à l'Arbitrage International Commercial, 120 ACADÉMIE DE DROIT INTERNATIONAL, RECUEIL DES COURS 568.

Liebscher, Christoph (2013), Vienna Rules, in INSTITUTIONAL ARBITRATION 316 (Rolf A. Schütze ed.).

Manner, Simon (2014), $\$ 11$ DIS-SchO, in ICC-SCHO/DIS-SCHO: PRAXISKOMMENTAR ZU DEN SCHIEDSGERICHTSORDNUNGEN (Jan Heiner Nedden \& Axel Benjamin Herzberg eds.).

Mo, John (2000), Probing the Uniformity of the Arbitration System in the $P R C, 17(3)$ JOURNAL OF INTERNATIONAL ARBITRATION 1.

Nedden, Jan Heiner \& Axel Benjamin Herzberg (2014), Art.1/Anh.I, II ICC-SchO, in ICC-SCHO/DIS-SCHO: PRAXISKOMMENTAR ZU DEN SCHIEDSGERICHTSORDNUNGEN 11 (Jan Heiner Nedden \& Axel Benjamin Herzberg eds.).

Nedden, Jan Heiner \& Axel Benjamin Herzberg (2014), Einleitung, in ICCSCHO/DIS-SCHO: PRAXISKOMMENTAR ZU DEN 
SCHIEDSGERICHTSORDNUNGEN 1 (Jan Heiner Nedden \& Axel Benjamin Herzberg eds.).

Nicholls, Anthony C. \& Christopher Bloch (2014), ICC Hybrid Arbitrations Here to Stay: Singapore Courts' Treatment of the ICC Rules Revisions in Article 1(2) and 6(2), 31 JOURNAL OF INTERNATIONAL ARBITRATION 393.

Patocchi, Paolo Michele \& Tilman Niedermaier (2013), UNCITRAL Rules, in InStitutional ARBITRATION 1007 (Rolf A. Schütze ed.).

Perales Viscasillas, Pilar (2014), The Role of Arbitral Institutions Under the 2010 UNCITRAL Arbitration Rules, 6 LIMA ARBITRATION 26.

Racine, Jean-Babtiste (2010), Note, 22 janvier 2010, Tribunal de Grande Instance de Paris, 2010(3) REVUE DE L'ARBITRAGE 571.

Reiner, Andreas \& Christian Aschauer (2013), ICC Rules, in InSTITUTIONAL ARBITRATION 38 (Rolf A. Schütze ed.).

Sanders, Pieter (1977), Commentary on UNCITRAL Arbitration Rules, 2 YEARBOOK OF COMMERCIAL ARBITRATION 172.

Schäfer, Friederike (2017), Institutionelle Schiedsgerichtsbarkeit Allgemeines, in HANDBUCH SCHIEDSGERICHTSBARKEIT 9308 (Hellwig Torggler et al. eds.).

Schilling, Alexander (2014), $\S 7$ DIS-SchO, in ICC-SCHO/DIS-SCHO: PRAXISKOMMENTAR ZU DEN SCHIEDSGERICHTSORDNUNGEN (Jan Heiner Nedden \& Axel Benjamin Herzberg eds.).

Schlaepfer, Anne Véronique \& Angelina M. Petti (2013), Institutional Versus Ad Hoc Arbitration, in INTERNATIONAL ARBITRATION IN SWITZERLAND: A HANDBOOK FOR PRACTITIONERS 13 (Elliott Geisinger \& Nathalie Voser eds., 2d. ed.).

Schütze, Rolf A. (2013), Introduction, in INSTITUTIONAL ARBITRATION 1 (Rolf A. Schütze ed.).

Schwab, Karl Heinz \& Gerhard Walter (2000), Kapitel 41. Grundlagen des Internationalen Schiedsverfahrens, in SCHIEDSGERICHTSBARKEIT (Schwab \& Walter et al. eds.).

Schwab, Karl Heinz \& Gerhard Walter (2005), Kapitel 41. Grundlagen des Internationalen Schiedsverfahrens, in SCHIEDSGERICHTSBARKEIT, 7th ed.

Slate II, William K. (1996), International Arbitration: Do Institutions Make a Difference?, 31 WAKE FOREST LAW REVIEW 41.

Smit, Robert H. (2005), Mandatory ICC Arbitration Rules, in LIBER AMICORUM IN HONOUR OF ROBERT BRINER 845.

Stumpe, Friederike \& Heiko A. Haller (2014), $\$ 32$ DIS-SchO, in ICCSCHO/DIS-SCHO: PRAXISKOMMENTAR ZU DEN SCHIEDSGERICHTSORDNUNGEN (Jan Heiner Nedden \& Axel Benjamin Herzberg eds.). 
Tao, Jingzhou \& Clarisse von Wunschheim (2007), Articles 16 and 18 of the PRC Arbitration Law: The Great Wall of China for Foreign Arbitration Institutions, 23(2) ARBITRATION INTERNATIONAL 309.

Timár, Kinga (2013), The Legal Relationship Between the Parties and the Arbitral Institution, 2013(1) ELTE LAW JOURNAL 103.

Veeder, V.V. (1998), The New 1998 LCIA Rules, in YEARBOOK COMMERCIAL ARBITRATION 1998: VOLUME XXIII 366 (Albert Jan van den Berg ed.).

Vigras, Bertie (1993), The Role of Institutions in Arbitration, in HANDBOOK OF ARBITRATION PRACTICE 461 (Ronald Bernstein \& Derek Wood et al. eds., 2d ed.).

Vogel, Hanspeter (1994), Institutionalisierte Schiedsgerichtsbarkeit, in RECHT UND JURISTEN IN HAMBURG 22.

von Levetzow, Meike (2014), 339 DIS-SchO, in ICC-SchO/DIS-SchO: PRAXISKOMMENTAR ZU DEN SCHIEDSGERICHTSORDNUNGEN (Jan Heiner Nedden \& Axel Benjamin Herzberg eds.).

Wehrli, Daniel B. et al., Management of the Proceedings and Quality Control Under the Swiss Rules, in THE SWISS RULES OF INTERNATIONAL ARBITRATION 87 (Gabrielle Kaufmann-Kohler \& Blaise Stucki eds.).

Willems, Jane (2017), The Arbitrator's Jurisdiction at Risk: The Case of Hybrid and Asymmetrical Arbitration Agreements, in THE POWERS AND Duties of AN ARbitrator: Liber AMICORUM PiERrE A. KARRER 403 (Patricia Shaugnessy \& Sherlin Tung eds.).

Winstanley, Adrian (2005), Party Autonomy and Institutional Rules, in 8TH BIENNIAL IFCAI CONFERENCE.

Winstanley, Adrian (2010), Review of the London Court of International Arbitration, in INTERNATIONAL COMMERCIAL ARBITRATION PRACTICE: 21ST CENTURY PERSPECTIVES 3 (Horacio Grigera Naón ed.).

Wüstemann, Tina \& Cesare Jermini (2005), Article 15, in SWISS RULES OF INTERNATIONAL ARBITRATION: COMMENTARY (Tobias Zuberbühler et al. eds.).

Zhou, Jian (2006), Arbitration Agreements in China: Battles on Designation of Arbitral Institution and Ad Hoc Arbitration, 23(2) JOURNAL OF INTERNATIONAL ARBITRATION 145.

Zitelmann, Ernst (1900), Aufgaben und Bedeutung der Rechtsvergleichung, 5 DEUTSCHE JURISTEN-ZEITUNG 329.

\section{$\underline{\text { Cases }}$}

Bovis Lend Lease Private Limited v. Jay-Tech Marine \& Projects Private Limited, [2005] SGHC 91 (Singapore).

Bundesgerichtshof [BGH] [Federal Court of Justice] December 2, 1982, NEUE JURISTISCHE WOCHENSCHRIFT [NJW] 1268, 1983 (Germany). 
Cassazione Sezione Civile [Cass.], April 17, 1978, 4 YEARBOOK OF COMMERCIAL ARBITRATION 282 (1979) (Italy).

Corte di Appello di Ancona [App.], June 8, 1981, 8 YEARBOOK of COMMERCIAL ARBITRATION 389 (1983) (Italy).

Exxon Neftegas Limited. v. WorleyParsons Limited, Supreme Court of the State of New York, County of New York, Order of 16 July 2014, Case no. 654405/2013, per Ramos J.

FG Hemisphere Associates LLC v. Democratic Republic of Congo [2010] NSWSC 1394 (Australia).

HKL Group Company Limited v. Rizq International Holdings Private Limited, [2013] SGHCR 5 (Singapore).

Insigma Technology Company Limited v. Alstom Technology Limited, [2009] SGCA 24, 3 Singapore Law Reports (Reissue) 936 (Singapore).

Insigma Technology Company Limited v. Alstom Technology Limited, [2008] SGHC 134 (Singapore).

Nachmani v. By Design, LLC, 901 N.Y.S.2d 838 (1st Department 2010).

Prostyakov v. Masco Corporation, 513 F.3d 716 (7th Circuit 2008).

Russian Federation v. I.M. Badprim S.R.L., Svea Court of Appeal, Judgment of 23 January 2015, Case no. 2454-14.

Sentencia Tribunal Supremo [S.T.S.], October 8, 1981, 8 YEARBOOK OF COMMERCIAL ARBITRATION 406 (1983) (Spain).

Subway Systems Australia Proprietary Limited v. Aaron Ireland and Lynette Ireland [2013] VSC 550 (Australia).

Top Gains Minerals Macao Commercial Offshore Limited v. TL Resources Private Limited, [2015] C.F.I. 2101(Hong Kong).

Tribunal de Grande Instance [TGI] [ordinary court of original jurisdiction] Paris, January 22, 2010, 10/50604, 571 (France).

York Research Corporation v. Landgarten, 927 F.2d 119 (2d Circuit 1991).

\section{$\underline{\text { Regulatory Sources }}$}

American Arbitration Association (AAA) Commercial Arbitration Rules and Mediation Procedures (2013), https://www.adr.org/sites/default/fi les/Commercial\%20Rules.pdf.

Arbitration Act 2005 (Malaysia).

Arbitration Ordinance, (2014) Cap. 609 (Hong Kong).

International Arbitration Regulations 2011 (Cth) s 4 (Australia).

International Centre for Dispute Resolution (ICDR) International Dispute Resolution Procedures (2014), https://www.adr.org/sites/default/files/ ICDR\%20Rules\%20English\%20Version\%20June\%202014.pdf.

Singapore International Arbitration Act 2002, c. 143A (Singapore).

United Nations Commission on International Trade Law (UNCITRAL) Arbitration Rules (2010). 
United Nations Commission on International Trade Law (UNCITRAL) Arbitration Rules (1976).

United Nations Commission on International Trade Law Model Law (UNCITRAL) Model Law on International Commercial Arbitration (2006), http://www.uncitral.org/pdf/english/texts/arbitration/ml-arb/0786998_Ebook.pdf.

Vienna International Arbitral Centre (VIAC) of the Austrian Federal Economic Chamber Rules of Arbitration and Conciliation (2006).

Vienna International Arbitration Centre (VIAC) Rules of Arbitration and Mediation (2013).

Zuigao Renmin Fayuan Kuanyu Shihyung Zhunghua Renmin Guongheguo Chungtsaifa Jogan Wenti de Chiehhsieh [Interpretation of the Supreme People's Court concerning Some Issues on Application of the Arbitration Law of the People's Republic of China] (China).

Other Sources

Convention on the Recognition and Enforcement of Foreign Arbitral Awards, opened for signature June 15, 1958, 330 U.N.T.S. 38.

European Convention on International Commercial Arbitration, opened for signature April 21, 1961, 484 U.N.T.S. 364.

G.A. Res. 31/98 (December 15, 1976).

G.A. Res. 65/22 (December 6, 2010).

Note by the Secretariat on Settlement of Commercial Disputes: Recommendations to Assist Arbitral Institutions and Other Interested Bodies with Regard to Arbitration Under the UNCITRAL Arbitration Rules, as Revised in 2010, 43 YEARBOOK (UNCITRAL) 251 (2012).

Recommendations to Assist Arbitral Institutions and Other Interested Bodies with Regard to Arbitrations Under the UNCITRAL Arbitration Rules Adopted at the Fifteenth Session of the Commission, 13 YEARBOOK (UNCITRAL) 420 (1982).

U.N. GAOR, 61th Sess., U.N. Doc. A/61/17 (July 14, 2006).

U.N. Secretary-General, Settlement of Commercial Disputes: Revision of the UNCITRAL Arbitration Rules, U.N. Doc. A/CN.9/703 (March 5, 2010). 
